University of Florida Levin College of Law

UF Law Scholarship Repository

UF Law Faculty Publications

Faculty Scholarship

$6-2013$

Deconstructing and Reconstructing Hot News: Toward a Functional Approach

Jeffrey L. Harrison

University of Florida Levin College of Law, harrisonj@law.ufl.edu

Robyn Shelton

Follow this and additional works at: https://scholarship.law.ufl.edu/facultypub

Part of the Communications Law Commons, First Amendment Commons, and the Intellectual

Property Law Commons

Recommended Citation

Jeffrey L. Harrison \& Robyn Shelton, Deconstructing and Reconstructing Hot News: Toward a Functional Approach, 34 Cardozo L. Rev. 1649, available at http://scholarship.law.ufl.edu/facultypub/384

This Article is brought to you for free and open access by the Faculty Scholarship at UF Law Scholarship Repository. It has been accepted for inclusion in UF Law Faculty Publications by an authorized administrator of UF Law Scholarship Repository. For more information, please contact kaleita@law.ufl.edu. 


\title{
DECONSTRUCTING AND RECONSTRUCTING HOT NEWS: TOWARD A FUNCTIONAL APPROACH
}

\author{
Jeffrey L. Harrison \& Robyn Shelton ${ }^{\dagger}$
}

\section{TABLE OF CONTENTS}

INTRODUCTION 1650

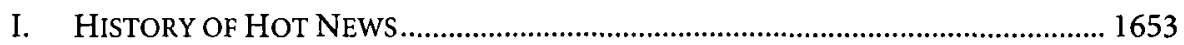

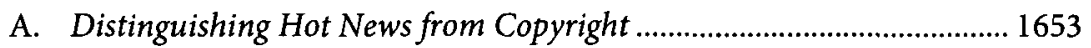

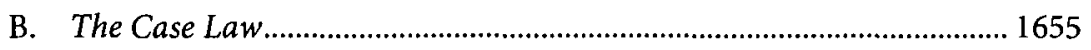

1. International News Service v. Associated Press............................ 1655

2. NBA v. Motorola ..................................................................... 1656

3. Barclays $v$. Theflyonthewall.com ............................................... 1658

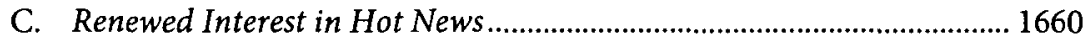

II. DESIGNING A HOT NEWS POLICY ................................................................... 1665

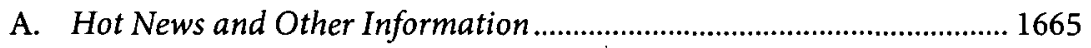

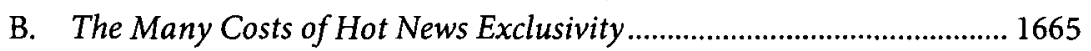

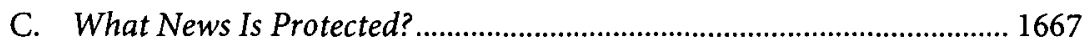

D. Can the Hot News Period of Exclusivity Be Varied? .............................. 1668

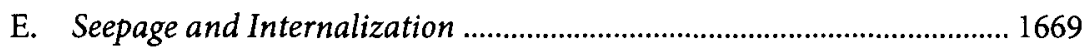

F. A Hot News Policy: Preliminary Formulation ...................................... 1670

III. HOT NEWS PROPOSALS EXPLORED BY THE FTC.................................................. 1671

A. Encourage More States to Adopt Hot News .............................................. 1671

B. Abolish the Common Law Tort and Add Hot News to the Existing

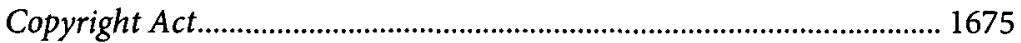

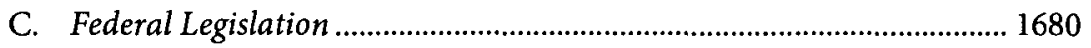

1. First Amendment Concerns....................................................... 1681

2. The Attribution Alternative .................................................... 1684

IV. FEDERAL LEGISLATION AS THE BETTER ALTERNATIVE...................................... 1684

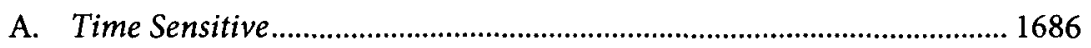

† Jeffrey Harrison is the Stephen O'Connor Chair and Professor of Law, University of Florida College of Law. Robyn Shelton, J.D. University of Florida College of Law, is currently Law Clerk to the Hon. Elizabeth Jenkins, U.S. Magistrate Judge, Middle District of Florida. 
B. Effort and Expense.

C. Direct Competition …………………………………………………...... 1687

D. What Kind of News Is Protected? ........................................................... 1688

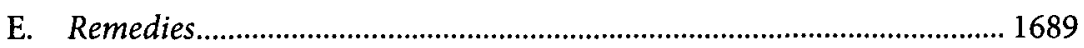

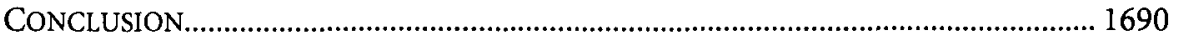

\section{INTRODUCTION}

Hot news is factual, time-sensitive information ranging from baseball scores to the outbreak of war. In recent years, hot news has found its own niche among legal scholars and courts. 1 When deconstructed, though, hot news is simply information and, like most information, it has a public good character. The problem ultimately is that news is non-excludable and non-rivalrous-discoverers or creators of hot news cannot exclude others from using the news and hot news is not destroyed when used.2 This means it may be produced at levels that are less than optimal. ${ }^{3}$

To understand this issue in context, consider hot news from both sides of the quandary presented by public goods. First, why would a

1 Kurt Fernstrom, Comment, The NBA May Own the Game, but It Doesn't Own the Score: A Case Comment on NBA v. Motorola, 22 RUTGERS L. REC. 5, 6 (1997); Lauren M. Gregory, Note, Hot Off the Presses: How Traditional Newspaper Journalism Can Help Reinvent the "Hot News" Misappropriation Tort in the Internet Age, 13 VAND. J. ENT. \& TECH. L. 577, 587-88 (2011); Jeena Moon, Note, The "Hot News" Misappropriation Doctrine, the Crumbling News Industry, and Fair Use as Friend and Foe: What Is Necessary to Preserve "Hot News," 28 CARdozo ARTS \& ENT. L.J. 631, 633 (2011); Eric P. Schmidt, Note, Hot News Misappropriation in the Internet Age, 9 J. TELECOMM. \& HigH TECH. L. 313, 315 (2011) (noting that the so-called "alternative media" relies on the mainstream media to survive). For more on the controversy restricting the dissemination of real-time sports scores, see Clay Calvert, Kayla Gutierrez \& Christina Locke, All the News That's Fit to Own: Hot News on the Internet of the Commodification of News in Digital Culture, 10 WAKE FOREST INTELL. PROP. L.J. 1, 22 (2009); Michelle R. Hull, Sports Leagues' New Social Media Policies: Enforcement Under Copyright Law and State Law, 34 COLUM. J.L. \& ARTS 457 (2011); Gary R. Roberts, The Scope of the Exclusive Right to Control Dissemination of Real-Time Sports Event Information, 15 STAN. L. \& POL'Y REV. 167 (2004); Louis Klein, Comment, National Basketball Association v. Motorola, Inc.: Future Prospects for Protecting Real-Time Information, 64 BROOK. L. REV. 585 (1998); Adam L. Sheps, Note, Swinging for the Fences: The Fallacy in Assigning Ownership to Sports Statistics and Its Effect on Fantasy Sports, 38 CONN. L. REv. 1113 (2006); Marc S. Williams, Note, Copyright Preemption: Real-Time Dissemination of Sports Scores and Information, 71 S. CAL. L. REV. 445 (1998).

2 In more technical terms, there are positive externalities associated with information including so-called "hot news." Positive externalities are the benefits of an activity that the person or entity engaged in the activity is unable to capture or, more technically, internalize. See JEFFREY L. HARRISON \& JULES THEEUWES, LAW AND ECONOMICS 58 (2008).

3 Id. at 72; see also Joseph Stiglitz, Knowledge as a Global Public Good, in GlOBal PUBLIC GOODS: INTERNATIONAL COOPERATION IN THE 21ST CENTURY 308 (Inge Kaul, Isabelle Grunberg \& Marc A. Stern eds., 1999); Gert Verschraegen \& Michael Schiltz, Knowledge as a Global Public Good: The Role and Importance of Open Access, 2 SOCIETIES WITHOUT BORDERS $157,158-59$ (2007). 
newspaper hire reporters, editors, photographers, and graphic artists to gather and report the news if, once published, the information can be used and reported by anyone else? Similarly, why would a local television station invest in first-hand reporting if it knows that another news organization will do the grunt work for it? In effect, whatever return there might be from original reporting is quickly taken by others as they make use of the same information without making a comparable investment. In what game theorists call the "chicken game," 4 a stand-off can occur with neither party producing what might be quite marketable but for the free riding problem.

The critical element in hot news is lead time. In periods of less technological sophistication, the discoverer and reporter of news could depend on lead time, even if only a few hours, during which it was the exclusive source of the information. In today's internet-based world, lead time is nonexistent. The most painstakingly gathered and expensive fact-based research can be re-reported within moments of its publication. This inevitably decreases the incentive to do original reporting.

A public response, in the form of state or federal legislation, to a shortage of hot news entails a public investment in a legal regime designed to protect exclusivity for a limited time. During that time, those first discovering the news and reporting it can internalize the benefits of their efforts. When viewed from this perspective, certain standards are important. Society gains the most when hot news is discovered and reported as long as the benefits, however defined, 5 outweigh its costs and those costs are incurred by those most efficient at discovering and producing the news. This leads to several sub-goals. First, there is no reason to protect hot news that would be reported without public intervention. Second, care must be taken to define the type of news that will be protected. In particular, hot news should have a functional definition-one that is consistent with the goal of ensuring news that otherwise would be stifled by the free-rider effect is published. This is a tall order and it is doubtful that a hot news policy can follow the functional definition completely. Nevertheless, without a target, efforts to develop a sensible hot news policy are likely to fall short of the goal of maximizing useful fact finding and reporting while avoiding unnecessary costs.

Although news gathering and reporting has a cost, so does a policy of allowing exclusivity to encourage the same gathering and reporting. For example, during the period of exclusivity, the reporting entity may

4 See Charles J. GoETZ, LAW AND ECONOMICS 29-32 (1984).

5 In traditional economic circles, the costs and benefits might be monetized. In other contexts, the view may be that value cannot be monetized. This Article steers clear of that debate. 
have a degree of monopoly or market power that allows the entity to increase the cost of access to the information. In addition, others will not be able to report the information themselves even though wider dissemination may be beneficial to the public. Finally, any system of regulation involving an exclusivity policy will create administrative costs. These costs are also part of the analysis.

The next Part describes the current state of hot news law. It is a somewhat messy picture. It shows that the current, state-by-state approach is out of sync with technology. Geography and political borders have little to do with communications markets, but the current system would only be rational if they did. Part III examines some of the issues that must be addressed in developing a functional and a rational approach to hot news. It describes the general requirements of such a system. Part IV assesses three proposals explored by the Federal Trade Commission (FTC). It uses the standards developed in Part III as a basis of comparison. Part $\mathrm{V}$ describes the specifics for proposed federal legislation.

Before those matters are considered, one important clarification is in order. A great deal of recent interest in hot news is linked to the desperate plight of newspapers. ${ }^{6}$ Traditionally, newspapers have been the most productive news gatherers. 7 They are also most in need of a solution to survive because their investments are substantial and lead time has been cut to zero. Moreover, they are the least likely to free ride on others.

As a consequence, hot news can be framed as a tool to preserve newspapers. However, those who view hot news issue in terms of saving ${ }^{8}$ or not saving 9 newspapers miss the critical point. Newspapers may or may not persevere, 10 but the more important problem is providing sufficient protection so that any entity will invest what is necessary to gather and report information.

6 See infra notes 77-93 and accompanying text.

7 Gregory, supra note 1, at 588; Moon, supra note 1, at 632-33; Schmidt, supra note 1, at 315.

8 DAN MARBuRger \& DAVID MARBURGer, REVIVING THE ECONOMIC VIABILITY OF NEWSPAPERS AND OTHER ORIGINATORS OF DAILY NEWS CONTENT (2009), available at http://www.bakerlaw.com/files/Uploads/Documents/News/Articles/MainAnalysis.pdf.

9 See, e.g., Heather Sherrod, The "Hot News" Doctrine: It's Not 1918 Anymore-Why the "Hot News" Doctrine Shouldn't Be Used to Save the Newspapers, 48 Hous. L. REV. 1205 (2012).

10 Eric Alterman, Out of Print: The Death and Life of the American Newspaper, NEw YORKER, Mar. 31, 2008, at 48 (hypothesizing that newspapers will not endure as printed publications). 


\section{HISTORY OF HOT NEWS}

\section{A. Distinguishing Hot News from Copyright}

It is tempting to think that the hot news dilemma can be solved by simply granting a copyright to the first finder of the news."11 Barring a revision in the law, 12 however, copyright does not protect facts. Copyright is designed to encourage creative activities. Facts are not created but "discovered."

In fact, the concepts of news and copyrightable works have different roots. Hot news misappropriation is a judicially created doctrine. ${ }^{13}$ There is no universally accepted definition for the term, but hot news generally applies to time-sensitive information gathered with effort and expense. ${ }^{14}$ Though sometimes described as breaking news, hot news is not limited to coverage of events that are unfolding in realtime, such as a plane crash or election results. Yet hot news necessarily includes a time-related element, including stock tips that have the most value before the market opens or a listing of movie show times that must be updated regularly. 15

In contrast, copyright protection flows directly from the U.S. Constitution, which grants the government authority to "secur[e] for limited Times to Authors and Inventors the exclusive Right to their respective Writings and Discoveries." 16 Carried out through the federal Copyright Act, the protection covers "original works of authorship" 17 embodied in everything from the label on a shampoo bottle ${ }^{18}$ to a novel penned by a Nobel laureate. However, copyright only shields the original expression within the work-not facts, ideas, or concepts. 19

11 See, e.g., Owning the News: Copyrighting Facts as well as Words, ECONOMIST, June 26, 2010, at 63 (framing proposals to increase protection for news reporting as creating the potential to copyright facts).

12 One of the Federal Trade Commission proposals contemplates such a revision. See infra Part IV.

13 See Moon, supra note 1 , at 632.

14 Id. at 642 (explaining that "hot news is, by its very nature, time sensitive").

15 See, e.g., Lowry's Reports, Inc. v. Legg Mason, Inc., 271 F. Supp. 2d 737, 756 (D. Md. 2003) (explaining that under Maryland law, the information in a hot news claim must be "highly time sensitive").

16 U.S. CONST. art. I, $\$ 8, \mathrm{cl} .8$.

17 The Copyright Act extends copyright to "original works of authorship fixed in any tangible medium of expression." 17 U.S.C. $\$ 102$ (a) (2012).

18 See Quality King Distribs. Inc., v. L'anza Research Int'l Inc., 523 U.S. 135 (1998) (involving the right holder's ability to stop importation of products bearing its copyright, which was embodied in the labeling for L'anza shampoo).

19 The Copyright Act explains: "In no case does copyright protection for an original work of authorship extend to any idea, procedure, process, system, method of operation, concept, principle, or discovery, regardless of the form in which it is described, explained, illustrated, or embodied in such work." 17 U.S.C. $\$ 102(\mathrm{~b})$. This distinction is called the idea-expression 
Thus, news reports are protected to the extent that a journalist's word choice, descriptions, and narratives are original expression. The underlying facts, as far as copyright law is concerned, are free for the taking. ${ }^{20}$

The U.S. Supreme Court emphasized this distinction in 1991 by proclaiming, "[t]hat there can be no valid copyright in facts is universally understood." 21 In Feist Publications v. Rural Telephone Service, the publisher of a telephone directory sued a competing directory for taking listings from its phone book. ${ }^{22}$ In rebuffing the claim, Justice O'Connor explained that copyright did not protect the alphabetical list of names, addresses, and telephone numbers. ${ }^{23}$ Copyright demands originality. ${ }^{24}$ Although the level of required originality is minimal, 25 facts cannot meet even that low burden. This is because facts, by definition, are not original expression. As Justice O'Connor elaborated, "[ $t]$ he distinction is one between creation and discovery: The first person to find and report a particular fact has not created the fact;... merely discovered its existence." 26 Hence, Feist made clear that U.S. copyright law does not reward effort, no matter how much labor was required to bring the facts to light. ${ }^{27}$ It is perhaps useful to note that Justice O'Connor's comments did rule out the protection of hot news under some other theory. She noted that while copyright cannot cover factual information, such "fruits" may be

dichotomy. See, e.g., Edward Samuels, The Idea-Expression Dichotomy in Copyright Law, 56 TENN. L. REV. 321 (1989). For the paradigm U.S. Supreme Court case on this topic, see Baker v. Selden, 101 U.S. 99 (1879) (concluding that the plaintiff could not prevent others from using the idea underlying a new method of bookkeeping).

20 See N.Y. Mercantile Exch., Inc. v. Intercontinental Exch., Inc., 497 F.3d 109, 114 (2d Cir. 2007) ("[A]ll facts-scientific, historical biographical, and news of the day... may not be copyrighted and are part of the public domain available to every person." (alteration in original) (quoting Feist Publ'ns v. Rural Tel. Serv. Co., 499 U.S. 340, 348 (1991)) (internal quotation marks omitted)).

21 Feist, 499 U.S. at 344 (1991).

22 Id. at $342-43$.

23 See id. at 341 ("[Plaintiffs] selection of listings-subscribers' names, towns, and telephone numbers - could not be more obvious and lacks the modicum of creativity necessary to transform mere selection into copyrightable expression.").

24 See id. at 345 ("The sine qua non of copyright is originality. To qualify for copyright protection, a work must be original to the author."). The Court cited to The Trade-Mark Cases, which had established long ago that "originality is required" for a work to classify as a "writing" within the meaning of the U.S. Constitution. The Trade-Mark Cases, 100 U.S. 82, 93-94 (1879).

25 Feist, 499 U.S. at 362; see also Rogers v. Koons, 960 F.2d 301, 307 (2d Cir. 1992) ("[T]he quantity of originality that need be shown is modest-only a dash of it will do.").

26 Feist, 499 U.S. at 347.

27 Feist blatantly rejects a sweat-of-the-brow approach to copyright in American law. For more on the implications of Feist, see Jane C. Ginsburg, No "Sweat"? Copyright and Other Protections of Works of Information After Feist v. Rural Telephone, 92 COLUM. L. REV. 338 (1992). In contrast, the European Union is amenable to sweat-of-the-brow efforts with its EU Database Directive that protects the content of databases. See G.M. Hunsucker, The European Database Directive: Regional Stepping Stone to an International Model?, 7 FORDHAM INTELL. PROP. MEDIA \& ENT. L.J. 697, 704-09 (1997). 
protected "in certain circumstances... under a theory of unfair competition." 28

\section{B. The Case Law}

\section{International News Service v. Associated Press}

In the only hot news misappropriation case to reach the U.S. Supreme Court, the Associated Press (AP) had been granted an injunction to keep rival International News Service (INS) from taking AP dispatches from the frontlines of World War I, rewriting them, and transmitting them as INS articles. 29 The Court upheld the injunction, and in doing so, famously declared that AP had a "quasi-property" right in its news reports. 30 This limited right allowed AP to prevent competitors from reaping where they had not sown, 31 but AP could not block the public from using the facts in its reports. ${ }^{32}$ The contours of this quasi-property right have been debated exhaustively in the scholarly literature. ${ }^{33}$ However, the central holding of INS became moot in 1938 when the Supreme Court abrogated federal common law in Erie Railroad Co. v. Tompkins. ${ }^{34}$ Consequently, the Supreme Court has cited INS for the general proposition that facts are not copyrightable ${ }^{35}$ but has steered clear of the case's substantive rule. Moreover, a few years after Erie, the Court explained that it considers "whether or not given conduct is tortious" to be a "question of state law," thereby leaving hot news misappropriation to state discretion. ${ }^{36}$ Thus, the doctrine has endured only in states that embraced the theory under common law. ${ }^{37}$

\footnotetext{
28 Feist, 499 U.S. at 354.

29 Int'l News Serv. v. Associated Press, 248 U.S. 215, 231-32 (1918).

$30 \mathrm{Id}$. at 236.

31 In one of the most-quoted passages from the case, the Court stated that in appropriating AP's information, INS “is endeavoring to reap where it has not sown, and by disposing of it to newspapers that are competitors of complainant's members is appropriating to itself the harvest of those who have sown." Id. at 239-40. The Court was referring to Galatians 6:7: "God is not mocked, for whatever a man sows, that he will also reap."

32 Int'l News Serv., 248 U.S. at 236.

33 See Maya Alexandri, The International News Quasi-Property Paradigm and Trademark Incontestability: A Call for Rewriting the Lanham Act, 13 HARV. J.L. \& TECH. 303, 311-34 (2000) (analyzing the ambiguous property status of news as created by the INS case).

34304 U.S. 64, 78 (1938) ("There is no federal general common law."). Even before INS's legal authority was undermined by Erie, courts were skeptical about its reach. In 1929, Judge Learned Hand declined to extend the hot news doctrine in a case involving misappropriation of fabric designs. Cheney Bros. v. Doris Silk Corp., 35 F.2d 279 (2d Cir. 1929). Hand concluded that INS was bound tightly to its facts, otherwise courts would be conflicting "flagrantly" with patent and copyright law. Id. at 280.

35 See, e.g., Feist Publ'ns v. Rural Tel. Serv. Co., 499 U.S. 340, 353-54 (1991); Harper \& Row Publishers, Inc. v. Nation Enters., 471 U.S. 539, 556 (1985).

36 Fashion Originators' Guild, Inc. v. FTC, 312 U.S. 457, 461, 468 (1941) (declining to
} 
Questions about the viability of hot news arose after Congress overhauled the Copyright Act in 1976, ${ }^{38}$ rewriting the Act's preemption provision to emphasize that all legal rights "within the general scope of copyright ... are governed exclusively by this title." 39 The language of section 301 begged the question: Did hot news misappropriation survive the 1976 amendments? The Second Circuit answered affirmatively in 1997, but in the process crafted a restricted version of the hot news doctrine.

\section{NBA v. Motorola}

In 1996, Motorola began selling the SportsTrax pager that provided scores and other information about professional basketball games. 40 Before launching the pager, Motorola had been in licensing negotiations with the National Basketball Association (NBA), which kept tight control over the dissemination of its real-time scores.41 When negotiations fizzled, Motorola relayed the scoring updates over its pager anyway. ${ }^{42}$ The NBA sued, alleging copyright infringement and common law misappropriation, along with other claims. 43

The district court granted the NBA a permanent injunction barring Motorola from disseminating the game scores. ${ }^{44}$ The Second Circuit reversed ${ }^{45}$ in a much-analyzed opinion ${ }^{46}$ authored by Judge Winter, who

address a tortious claim of "style piracy" involving the design of women's garments because, under the Erie holding, "whether or not given conduct is tortious is a question of state law").

37 See infra notes $93-96$ and accompanying text.

38 For a discussion of the 1976 amendments, see DAVID NIMMER, COPYRIGHT ILLUMINATED: REFOCUSING THE DIFFUSE U.S. STATUTE 93-107 (2008).

39 The preemption provision embodied in section 301 of the Copyright Act provides:

[A]ll legal or equitable rights that are equivalent to any of the exclusive rights within the general scope of copyright as specified by section 106 in works of authorship that are fixed in a tangible medium of expression and come within the subject matter of copyright as specified by sections 102 and 103, whether created before or after that date and whether published or unpublished, are governed exclusively by this title. Thereafter, no person is entitled to any such right or equivalent right in any such work under the common law or statutes of any State.

17 U.S.C. $\$ 301$ (a) (2012).

40 Nat'l Basketball Ass'n v. Motorola, Inc., 105 F.3d 841, 843 (2d Cir. 1997).

41 At the time, the NBA restricted reporters covering its games to no more than three scoring updates per quarter. Fernstrom, supra note 1, at 6 . For more on the controversy restricting the dissemination of real-time sports scores, see Hull, supra note 1; Klein, supra note 1; Roberts, supra note 1; Sheps, supra note 1.

42 See Fernstrom, supra note 1 , at 6.

43 Nat'l Basketball Ass'n, 105 F.3d at 844 (listing the NBA's six asserted claims including "state law unfair competition by misappropriation").

44 Id.

$45 \mathrm{Id}$. at 846 .

46 The NBA v. Motorola decision has been a popular topic for law students writing Notes or Comments. See, e.g., William Nesnidal, Note \& Comment, The Story of The National Basketball 
drew three main conclusions. First, the amended Copyright Act did not preempt the hot news misappropriation doctrine, ${ }^{47}$ leaving states free to protect hot news if they so desired. Secondly, however, the court explained that hot news avoided preemption only because such claims fell outside copyright. To avoid clashing with the federal law, Judge Winter explained that a hot news claim should meet five elements: 1) the plaintiff generates or gathers the information at a cost; 2) the information is time-sensitive; 3 ) the defendant's use of the information constitutes free riding; 4) the defendant and plaintiff are direct competitors; and 5) the defendant's use of the information "substantially threaten $[\mathrm{s}]$ " the plaintiff's existence. 48

Thirdly, Judge Winter justified the hot news doctrine under a theory of property rights, expressly refuting the notion that the Supreme Court grounded INS in the law of unfair competition. ${ }^{49} \mathrm{He}$ opined:

INS is not about ethics; it is about the protection of property rights in time-sensitive information so that the information will be made available to the public by profit seeking entrepreneurs. If services like AP were not assured of property rights in the news they pay to collect, they would cease to collect it. The ability of their competitors to appropriate their product at only nominal cost and thereby to disseminate a competing product at a lower price would destroy the incentive to collect news in the first place. The newspaper-reading public would suffer because no one would have an incentive to collect "hot news." 50

In the end, Judge Winter nonetheless concluded that the NBA was not entitled to the doctrine's protection in this situation. ${ }^{51}$ The NBA failed to satisfy the criteria because Motorola was not competing directly with the basketball association and its conduct was not undermining the NBA's incentive to continue its business. ${ }^{22}$ It was also important to the Second Circuit's analysis that Motorola bore its own costs of collecting the scores by employing people to watch the games on television and

Association v. Motorola, 7 DEPAUL J. SPORTS L. \& CONTEMP. ProBS. 99 (2011); Claudia Werner, Case Note \& Comment, NBA v. Motorola \& Stats, Inc.: Real-Time Basketball ScoresNews or Property?, 7 DEPAUl-LCA J. ART \& ENT. L. 288 (1997); Monica Y. Youn, Note, Neither Intellectual nor Property, 107 YALE L.J. 267 (1997).

47 Nat'l Basketball Ass'n, 105 F.3d at 845 ("[I]t is generally agreed that a 'hot-news' INS-like claim survives preemption.").

$48 \mathrm{Id}$. at 852.

$49 \mathrm{Id}$. at 853 .

$50 \mathrm{Id}$.

51 Id. at 854 .

52 Id. at 853-54. As Judge Winter explained: "An indispensable element of an INS hotnews' claim is free riding by a defendant on a plaintiff's product, enabling the defendant to produce a directly competitive product for less money because it has lower costs. SportsT $\operatorname{rax}$ is not such a product." Id. at 854 . 
feed updates into its system. ${ }^{53}$ There simply was no free riding. ${ }^{54}$ This case left hot news misappropriation viable but limited. 55

The framework of Judge Winter is very close to the ideal as described later in this Article. ${ }^{56}$ However, one false step in the formula is the notion that the free riding must threaten the existence of the source of the hot news. More precisely, this requirement should be that it threatens the new gathering and reporting function of that source. It is also not clear that in applying his standard, Judge Winter had a firm grasp of the meaning of free riding. In effect, the NBA did not discover facts or produce them-the facts revealed themselves to anyone in attendance. Moreover, the purpose of the NBA investment was not to produce "scores." Thus, it is not clear that there was anything to be freeridden on.

\section{Barclays v. Theflyonthewall.com}

Fourteen years later, the Second Circuit modified its approach. ${ }^{57}$ In Barclays $v$. Theflyonthewall.com, the Fly was a subscription-only website that offered investment advice, stock tips, and other financial news. ${ }^{58}$ Barclays Capital Inc. and other investment firms ${ }^{59}$ sued the website in the Southern District of New York for publishing headlines revealing the recommendations that the firms were providing to their clients in written reports. ${ }^{60}$ During a typical day, the Fly was posting about 600 headlines that often advised investors to buy, sell, or hold various stocks based on the firms' insider reports. ${ }^{61}$ The Fly conducted no research

53 Id. at 853-54.

54 Id. at 854.

55 Some commentators applaud the Second Circuit's efforts to set clear boundaries for hot news. See, e.g., Jason R. Boyarski, Note, The Heist of Feist: Protection for Collections of Information and the Possible Federalization of "Hot News," 21 CARDOZO L. REV. 871, 893-94 (1999). Others have been critical of the Second Circuit for emphasizing a property-like right in information. See Shyamkrishna Balganesh, "Hot News": The Enduring Myth of Property in the News, 111 Colum. L. REV. 419, 423 (2011).

56 See infra text accompanying notes 206-232.

57 Barclays Capital Inc. v. Theflyonthewall.com (Barclays II), 650 F.3d 876, 898-900 (2d Cir. 2011). In the intervening years since $N B A$, district courts in the Second Circuit addressed hot news misappropriation at least twice. Silver v. Lavandeira, No. 08-cv-6522, 2009 WL 513031 (S.D.N.Y. Feb. 26, 2009) (rejecting hot news claim for taking facts from plaintiff's website); Associated Press v. All Headline News Corp., 608 F. Supp. 2d 454, 461 (S.D.N.Y. 2009) (declaring that hot news misappropriation remained viable under New York law).

58 Barclays $I I, 650$ F.3d at 879.

59 The other firms were Merrill Lynch; Morgan Stanley; and Pierce, Fenner \& Smith. Id. at 878.

$60 I d$. at 880 .

61 Barclays v. Theflyonthewall.com (Barclays N, 700 F. Supp. 2d 310, 323 (S.D.N.Y. 2010) (giving a headline example as "EQIX: Equinox initiated with a Buy at BofA/Merrill. Target $\$ 110 "$ ), rev'd in part, 650 F.3d 876 (2d Cir. 2011). At the time of the litigation, the Fly solely relied on individuals to leak copies of the investment reports to the website without the consent 
itself and made no recommendations of its own.62 In their hot news misappropriation claim, 63 the firms argued that the website was undercutting their businesses by allowing the public to get the firms' advice without going through (and paying fees for) their brokers. 64

The district court agreed. In a forty-three page opinion, the court analyzed the hot news claim under the NBA v. Motorola test and concluded that the Fly was misappropriating the information.65 Yet the court also recognized that the website was giving the public useful financial guidance.66 Seeking middle ground, the court created an injunction that gave the firms a temporary monopoly on their advice. The injunction barred the Fly from posting the tips until at least thirty minutes after the market opened. ${ }^{67}$ If the information became available during the business day, the Fly was barred from publishing it for two hours after the firms first released it.68 But even this slim injunction withered on appeal.

In explaining its reversal, the Second Circuit dissected its earlier decision in NBA v. Motorola and concluded that NBA did not impose a mandatory, five-element test for hot news. ${ }^{69}$ Instead, the Barclays court clarified that hot news misappropriation hinged on three key elements: "(1) the time-sensitive value of factual information, (2) the free-riding by a defendant, and (3) the threat to the very existence of the product or service provided by the plaintiff." 70 According to the court, the firms failed on the second and third elements because the Fly was not freeriding and the "very existence" of the firms was not in jeopardy.71 While the Fly was dulling the firms' thunder, the Second Circuit concluded

of the firms. Id. at 325 . The website advertised itself as being a fly on the wall inside Wall Street's "best houses and learning what they know when they know it." Id. at 323. In recent years, however, companies have given the Fly their written reports because they want to publicize their experts' opinions. Id. at 326.

62 Id. at 323 ("Fly does not conduct its own equity research or include any original research in its newsfeed.").

63 Barclays $I I, 650 \mathrm{~F} .3 \mathrm{~d}$ at 880 . The firms also won copyright infringement in the district court for verbatim copying of their reports. Id. The Fly did not challenge the copyright claims on appeal. $I d$.

64 Id. at $884-86$.

65 Barclays $I, 700$ F. Supp. $2 \mathrm{~d}$ at 334.

$66 \mathrm{Id}$. at 344 .

67 Id. at 347.

$68 \mathrm{Id}$.

69 Barclays $I I, 650$ F.3d at 901 (explaining that the NBA court's "sophisticated observations" were not "equivalent to a statutory command to which we or the district court are expected to adhere"). Although the Second Circuit rebuffed its own test, courts in other circuits had already adopted $N B A$ 's five-element framework as the law. These included the Seventh Circuit, see ConFold Pac. Inc. v. Polaris Indus. Inc., 433 F.3d 952, 960 (7th Cir. 2006), which cited NBA's hot-news test with approval, and the Central District of California, see X17, Inc. v. Lavandeira, 563 F. Supp. 2d 1102, 1104-06 (C.D. Cal. 2007), which found hot news misappropriation under the "persuasive" test created in NBA.

70 Barclays II, $650 \mathrm{~F} .3 \mathrm{~d}$ at 900 .

71 Id. at $902-04$. 
that the website's conduct was more akin to "breaking the news" than stealing it.72 In fact, this distinction was likely missed by Judge Winter. The court especially seemed swayed by the fact that the Fly attributed its buy-sell-hold advice to the firms themselves. ${ }^{73}$ Thus the website was giving credit where it was due. The investment firms went home emptyhanded.

It is not clear whether the court dropped two of judge Winter's requirements or implicitly subsumed them under its own three-step analysis. As will be clear, it is important to link free riding to the fact that the news was acquired at a cost. If news is simply happened upon or is a byproduct of another principal activity, the first reporting entity has little need to internalize the benefits of releasing the information to support it efforts. ${ }^{74}$ Similarly, if the original news carrier does not compete with the firm re-reporting the news, it will not lose returns that can be traced to its investment in news gathering. As discussed below, if these two steps are not implicitly contained in the remaining three, the hot news protection announced by the court was unnecessarily broad.

\section{Renewed Interest in Hot News}

In the period since the Barclays decision, there has been much speculation on the health of hot news misappropriation. Some claim the tort gasps on its deathbed; 75 others say it endures in weakened form. ${ }^{76}$

$72 \mathrm{Id}$. at 902 . Some interpret the Second Circuit as suggesting that attribution to the original source should vitiate hot news liability. Dorothy Heyl \& James R. Klaiber, The Future of "Hot News" Misappropriation After Barclays v. Theflyonthewall.com, 24 INTELL. PROP. \& TECH. L.J. 12, 13 (2012) (asserting that Barclays hints that "proper attribution of the source could exempt a fact copyist from liability"). In his dissent in International News Service v. Associated Press, Justice Holmes had argued that attribution would be sufficient to remedy the "palming off" at issue in hot news claims. Int'l News Serv. v. Associated Press, 248 U.S. 215, 248 (1918) (Holmes, J., dissenting) (stating that "suitable acknowledgment of the source is all that the plaintiff can require").

73 Barclays II, 650 F.3d at 903 (noting that the website "is hardly selling the Recommendation as its own. It is selling the information with specific attribution to the issuing Firm"). The court equated the Fly's reporting of the firms' financial tips with a newspaper's political endorsements or list of Tony award winners. Id. at 904.

74 See infra Part IV.

75 See Heyl \& Klaiber, supra note 72, at 13 (speculating that few claims can meet the Second Circuit's latest incarnation of the hot news doctrine). The authors offer a hypothetical to show when a hot news claim would stand after Barclays $I I$ : Website $X$ sends an employee to the county clerk's office daily to manually record the closing costs on real estate sales. $X$ then posts these transactions as a list-thus creating a noncopyrightable factual compilation. A competing website $Y$ takes the information immediately and posts it on its own site. The authors say that the website $X$ could obtain an injunction against website $Y$ based on hot news misappropriation, especially if they are direct competitors. Id. at 14 .

76 Ray Hashem, Note, Barclays v. TheFly: Protecting Online News Aggregators from the Hot News Doctrine, 10 Nw. J. TeCH. \& INTELl. Prop. 37, 53 (2011) (discussing how the Second Circuit left "the precise contours of the hot news doctrine more uncertain than ever" after 
Regardless, it would be hard to overstate the economic crisis that is fueling the backlash against news piracy, particularly from newspapers. ${ }^{77}$ While every media sector has suffered sharp losses since 2006, newspapers were hit hardest and continue to lose advertising revenue even while other sectors are starting to rebound. ${ }^{78}$ This, in itself, might not be troubling but there does not seem to be a substitute for the role traditional media play in informing the public. ${ }^{79}$ While readers increasingly get their news online from aggregation websites, the underlying reporting still comes from long-established organizations. 80 Websites do very little "first-generation reporting," ${ }_{11}$ instead "leech[ing]" information from mainstream publications that invest heavily in the newsgathering that sustains the entire industry. 82

True, online aggregators often provide links to the source websites; but this attribution does not translate into significant revenue for various reasons. ${ }^{83}$ For starters, few people click on the links in news

Barclays v. Theflyonthewall.com).

77 Newspaper advertising revenues have plummeted fifty-three percent since 2000 , when they peaked at $\$ 48.7$ billion. By 2010 , newspaper advertising revenue had fallen to $\$ 22.8$ billion. Rick Edmonds, Emily Guskin \& Tom Rosenstiel, State of the News Media 2011: An Annual Report on American Journalism-Newspapers: By the Numbers, PEW RESEARCH CTR.'S PROJECT FOR EXCELLENCE IN JOURNALISM, http://stateofthemedia.org/2011/newspapers-essay/data-page6 (last visited Mar. 1, 2013) [hereinafter Pew's State of the News Media 2011-Newspapers]; see also Richard Posner, Are Newspapers Doomed?, BECKER-POSNER BlOG (June 29, 2008, 2:07 PM), http://www.becker-posner-blog.com/2008/06/are-newspapers-doomed--posner.html (lamenting the dire condition of the newspaper industry, and noting that "younger people are much more comfortable getting information online," which is hastening the demise of the printed product).

78 Cable television networks, local television, and network news organizations reported revenue increases of six to seventeen percent from 2009 to 2010. Magazines reported a modest increase in revenue of $1.4 \%$. Only the newspaper industry lost an additional $6.3 \%$ in advertising revenues during that same time period. See State of the News Media 2011: An Annual Report on American Journalism-Key Findings, PEW RESEARCH CTR.'S PROJECT FOR EXCELLENCE IN JOURNALISM, http://stateofthemedia.org/2011/overview-2/key-findings (last visited Mar. 1, 2013).

79 Thomas Jefferson was an ardent believer in the media's importance in sustaining a democracy. He remarked in 1787 that "were it left to me to decide whether we should have a government without newspapers, or newspapers without a government, I should not hesitate to prefer the latter." Alan L. Golden \& James L. Golden, Thomas Jefferson's Perspectives on the Press as an Instrument of Political Communication, 37 AM. BEHAV. SCIENTIST 194 (1993). For a more recent discussion of the media's role in a democracy, see, for example, Jill Carroll, Foreign News Coverage: The U.S. Media's Undervalued Asset 13-14 (Harvard Kennedy Sch. of Gov't, Joan Shorstein Ctr. on the Press, Politics, and Pub. Policy Working Paper Series, Paper No. 2007-1, 2007), available at http://shorensteincenter.org/wp-content/uploads/2012/03/2007_01_ carroll.pdf ("Having many sources of good quality, in-depth, insightful, well-informed foreign reporting is essential to keeping the national debate vigorous and churning.").

80 Eric P. Schmidt, Hot News Misappropriation in the Internet Age, 9 J. TELECOMM. \& HiGH TECH. L. 313, 315 (2011) (noting that the so-called "alternative media" relies on the mainstream media to survive).

81 See Moon, supra note 1, at 639.

82 Id.; see also Gregory, supra note 1, at 581-82 ("[T]raditional newspapers buttress the entire news industry by generating the majority of all original news content.").

83 Peter R. Kann, Quality Reporting Doesn't Come Cheap: The Decline of Newspapers Is a 
blogs.84 Even more fundamentally, newspaper revenues depend overwhelmingly on the printed product. ${ }^{85}$ Online content only brings in a small fraction of a newspaper's income.86 Thus as newspaper circulation has dropped, so have advertising rates and corresponding profits. Newspapers have closed;87 laid off record numbers of staff members; 88 shuttered bureaus worldwide; 89 instituted mandatory, unpaid furloughs for remaining workers; 90 and generally tightened their belts. Yet nothing has stopped the financial hemorrhaging. As a result, the media are looking for new ways to make money. Licensing their content to websites and news aggregators is an appealing option..$^{91}$ But before any news organization can charge others to use factual information it has uncovered, ${ }^{92}$ it needs to establish a legitimate right to

Tragedy for Democracy. How Can It Be Stopped?, WaLL ST. J., Sept. 26, 2009, at A15 ("Online edition ad rates and online edition ad revenues are only small fractions of those in traditional print.").

84 Nate Anderson, Is Permission Needed to Retweet Hot News?, ARS TeCHNICA (Apr. 5, 2010, 10:36 PM), http://arstechnica.com/tech-policy/news/2010/04/is-permission-needed-toretween-hot-news.ars (explaining that people increasingly get news in short summaries on websites, but not by clicking through to the detailed articles on which the summaries are based); Brian Westley, How a Narrow Application of "Hot News" Misappropriation Can Help Save Journalism, 60 AM. U. L. REV. 691, 694 (2011) ("Assuming a site such as Gawker even bothers to link to the original story, there is often little reason for someone to read the same material twice.").

85 Newspapers derive eighty percent of their revenue from advertising in their print editions-mostly classified and retail. Jon Leibowitz, Chairman \& Comm'r, U.S. Fed. Trade Comm'n, Opening Remarks at the Federal Trade Commission News Media Workshop"Creative Destruction" or Just "Destruction": How Will Journalism Survive the Internet Age? (Dec. 1, 2009), available at http://www.ftc.gov/speeches/leibowitz/091201 newsmedia.pdf.

86 See Kann, supra note 83.

87 Janna Fisher, Sweet Fruit or Poisoned Apple? The Ipad's Effect on Newspapers, $10 \mathrm{~J}$. TELECOMM. \& HIGH TECH. L. 173, 175-77 (2012) ("Hundreds of daily newspapers have closed their doors in the last four years, including venerable publications such as the Honolulu Advertiser in Hawaii and the Rocky Mountain News in Denver."); see also NEWSPAPER DEATH WATCH, http://www.newspaperdeathwatch.com (last visited May 25, 2013) (chronicling the decline of newspapers); Closed Newspapers, PAPER CUTS, http://newspaperlayoffs.com/maps/ closed (last visited Mar. 25, 2013) (providing a map and a list of newspapers that have stopped publishing).

88 Fulltime newspaper staff peaked at 56,400 in 2000 . It fell $26.4 \%$ through 2009 . The Pew Research Center estimates that up to 1500 additional jobs were lost in 2010, resulting in total industry-wide cutbacks of nearly thirty percent since 2000. See Pew's State of the News Media 2011-Newspapers, supra note 77.

89 John Hughes, Opinion, U.S. Media Can't Cover the News if They Don't Cover the World, CHRISTIAN SCI. MONITOR, Feb. 7, 2007, at 9 (detailing closings of U.S. newspaper bureaus in South Africa, Russia, Bogota, and Jerusalem-often after decades of maintaining permanent staffing overseas).

90 David Kaplan, Gannett Warns of More Unpaid Furloughs, CBSNEWS.COM (Mar. 23, 2009), http://www.cbsnews.com/2100-502603_162-4886232.html (explaining that Gannett employees were required to take at least one week of unpaid leave in 2009).

91 See Balganesh, supra note 55, at 434 (asserting that the media's interest in creating a licensing market has sharpened its focus on the hot news misappropriation doctrine in recent years).

92 See Saul Hansell, The Associated Press to Set Guidelines for Using Its Articles in Blogs, N.Y. TIMES, June 16, 2008, at C7 (stating that AP pledged to challenge blogs that take too much 
those facts. Copyright clearly denies it ${ }^{93}$ - hence the focus on the hot news doctrine.

Current reactions to hot news are varied. Some are calling for federal legislation comparable to copyright that would grant propertylike rights in hot news, while others vehemently oppose such exclusivity as threatening First Amendment rights. ${ }^{44}$ In fact, the current "solution" is probably the worst of the possibilities 95 - some states treat the use of hot news by a party who did not gather it as a form of theft and label it misappropriation. 96

Some states seem to have no position at all.97 Underlying support for anything but a uniform approach is the deeply flawed idea that

information from AP stories but later did not); Mike Masnick, AP Will Sell You a License to Words It Has No Right to Sell, TECHDIRT (Aug. 3, 2009, 1:14 PM), http://www.techdirt.com/ articles/20090803/0344305756.shtml (deriding AP's effort to restrict free use of its content to a maximum of four words, thereafter charging $\$ 12.50$ for the use of five to twenty-five words).

93 See supra Part I.A.

94 The positions and their supporters are discussed infra in the text accompanying notes 130-204.

95 In both recent and distant cases, the doctrine of hot news misappropriation has befuddled and eluded plaintiffs. Compare Associated Press v. KVOS, Inc., 80 F.2d 575 (9th Cir. 1935) (finding a radio station liable for misappropriation for taking breaking-news reports from newspapers), rev'd on other grounds, 299 U.S. 269 (1936), and Bd. of Trade of Chi. v. Dow Jones \& Co., 456 N.E. 2d 84 (Ill. 1983) (barring the Board of Trade from using Dow's stock market index without permission under a theory of misappropriation), with Agora Fin. v. Samler, 725 F. Supp. 2d 491, 494-504 (D. Md. 2010) (finding that a misappropriation claim was preempted by copyright law), Rodriguez v. Heidi Klum Co., No. 05-cv-10218, 2008 WL 4449416 (S.D.N.Y. Sept. 30, 2008) (dismissing claim alleging misappropriation of the idea for the "Project Runway" television show because the claim did not meet the requirements of "hot news"), and Pinnacle Pizza Co., Inc. v. Little Caesar Enters., 395 F. Supp. 2d 891, 900-03 (D.S.D. 2005) (dismissing a misappropriation claim for the advertising idea of "Hot n' Ready" as being preempted by Copyright Act).

96 Only five states clearly recognize the tort: New York, see Banxcorp v. Costco Wholesale Corp., 723 F. Supp. 2d 596, 612-14 (S.D.N.Y. 2010) (denying motion to dismiss a hot news misappropriation claim against Costco for unauthorized sharing of Banxcorp data with customers); Illinois, see McKevitt v. Pallasch, 339 F.3d 530, 534 (7th Cir. 2003) (noting that Illinois had adopted the doctrine of hot news misappropriation); California, see Pollstar v. Gigmania, 170 F. Supp. 2d 974 (E.D. Cal. 2000) (denying motion to dismiss hot news misappropriation claim against defendant website, which allegedly was taking concert information from plaintiff's website); McCord Co. v. Plotnick, 239 P.2d 32 (Cal. Dist. Ct. App. 1951) (barring publication of bank credit rates that were copied from a trade newspaper); Missouri, see Fred Wehrenberg Circuit of Theatres, Inc. v. Moviefone, Inc., 73 F. Supp. 2d 1044 (E.D. Mo. 1999) (acknowledging that hot news misappropriation was a viable cause of action under Missouri law); and Pennsylvania, see Pottstown Daily News Publ'g Co. v. Pottstown Broad. Co., 192 A.2d 657 ( $\mathrm{Pa}$. 1963) (affirming order denying motion to dismiss because the misappropriation claim was viable under Pennsylvania law). Massachusetts is the sole jurisdiction to denounce it outright. Triangle Publ'ns v. New Eng. Newspaper Publ'g Co., 46 F. Supp. 198, 203 (D. Mass. 1942) ("Except where there has been a breach of trust or contract, it is not unfair competition in Massachusetts to use information assembled by a competitor."). But see Mark D. Robins, Will Massachusetts Adopt the Misappropriation Doctrine?, 43 Bos. B.J. 4 (1999) (speculating that Massachusetts might reverse course and adopt misappropriation because the Internet is aggravating the free-riding problem).

97 Florida case law sends mixed signals. In 1965, a Florida court hinted that the hot news doctrine would apply only when a defendant actually was misrepresenting itself as the plaintiff. 
geographic and political borders are somehow aligned with communications markets.

The media's predicament got Congress's attention in 2009 when three congressional hearings were convened during a six-month span. 98 Thereafter, the FTC announced that it would investigate the future of journalism. ${ }^{99}$ As part of the effort, the FTC held a two-day workshop in December 2009 entitled "How Will Journalism Survive the Internet Age?" 100 Then on May 24, 2010, the FTC released a draft report with tentative conclusions and policy recommendations on a range of measures. ${ }^{101}$ These suggestions are assessed in Part IV. First, however, it is important to describe a context in which that assessment can take place.

Herald Publ'g Co. v. Fla. Antennavision, Inc., 173 So. 2d 469 (Fla. Dist. Ct. App. 1965). However, a federal court in Florida's Middle District indicated in 2000 that the state recognized hot news more broadly, though it declined to apply the doctrine to the facts at issue. Morris Commc'ns Corp. v. PGA Tour, Inc., 117 F. Supp. 2d 1322 (M.D. Fla. 2000) (denying a newspaper's request for preliminary injunction to stop the PGA from delaying access to realtime golf scores). For a discussion of Morris and the legal issues surrounding real-time sports scores, see Andrea Freeman, Note, Morris Communications v. PGA Tour: Battle over the Rights to Real-Time Sports Scores, 20 BERKELEY TECH. L.J. 3 (2005).

98 See The Future of Newspapers: The Impact on the Economy and Democracy: Hearing Before the J. Econ. Comm., 111th Cong. (2009); The Future of Journalism: Hearing Before the Subcomm. on Commc'ns, Tech., \& the Internet of the S. Comm. on Commerce, Sci., \& Transp., 111 th Cong. (2009); A New Age for Newspapers: Diversity of Voices, Competition and the Internet: Hearing Before the Subcomm. on Courts \& Competition Policy of the H. Comm. on the Judiciary, 111 th Cong. (2009). In addition to hot news misappropriation, Congress explored tax breaks, antitrust exemptions, and possibly extending non-profit status to newspapers, among other topics. See Bruce W. Sanford, Bruce D. Brown \& Laurie A. Babinski, Saving Journalism with Copyright Reform and the Doctrine of Hot News, 26 CoMM. LAW 8, 9-10 (Dec. 2009) (explaining how the hot news doctrine may help the media curb free riding by competitors).

99 Fed. TRade Comm'n, Federal Trade Commission StafF Discussion Draft: POTENTIAL POLICY RECOMMENDATIONS TO SUPPORT THE REINVENTION OF JOURNALISM (2010) [hereinafter FTC DISCUSSION DRAFT], available at http://www.ftc.gov/opp/workshops/news/ jun15/docs/new-staff-discussion.pdf.

100 The FTC hosted additional workshops on journalism's survival, culminating in a daylong meeting at the National Press Club in Washington, D.C., on June 15, 2010. To access a video library of all the FTC meetings on the topic, see How Will Journalism Survive the Internet Age, FED. TRADE COMM'N, http://www.ftc.gov/opp/workshops/news/index.shtml (last visited Mar. 1, 2013) (providing a list of meetings with links to documents, transcripts, and webcasts).

101 FTC DISCUSSION DRAFT, supra note 99. Soon after releasing the document, the FTC issued a statement clarifying that the report did not represent the official position of the FTC. Press Release, Fed. Trade Comm'n, FTC Corrects Misinformation on Journalism Workshops and "Discussion Draft": Ideas are Compilation, not Recommendations from Agency (Jun. 6, 2010), available at http://www.ftc.gov/opa/2010/06/journalism.shtm. 


\section{Designing A Hot News Policy}

\section{A. Hot News and Other Information}

As noted in the Introduction, just as with other types of information, hot news is non-rivalrous and non-exclusive. Its primary distinction is that the value of hot news stems from its timeliness. Other information-nutritional information on food products, technical specifications, 102 warning labels, etc.,- -are also public in nature and free riding may occur, but the time element is largely irrelevant. In such cases, those who possess the information can simply be required to disclose it. In contrast, the possessor of hot news is not obligated to publish it. First, hot news is not pre-existing and there is no way to order, with any specificity, what is to be reported. In addition, in the more typical situation, the disclosure is ancillary to a different primary business. For example, a distributor of food products is not in the business of providing information about food and requiring the distributor to disclose nutritional information is not likely to prompt it to leave the business. In the case of hot news, providing news is the business and a disclosure requirement (or the absence of a period of exclusive use) may mean that the provider does leave the industry.

\section{B. The Many Costs of Hot News Exclusivity}

A policy of protecting hot news gives rise to a variety of costs. To start, affording a period of exclusivity to those discovering hot news can result in substantial waste. A grant of exclusivity for hot news would be similar to what exists in the context of patent law. Rivals may go after the latest news and one may scoop the other. As in the case of patent races 103 and other winner-take-all contexts, the resources invested by the losing competitors duplicate those of the winner but result in no private return. 104

102 See, e.g., Trade Regulation Rules, Labeling, and Advertising of Home Insulation, 44 Fed. Reg. 50218 (Aug. 27, 1979).

103 See, e.g., DENNIS W. CARLTON \& JEFFREY M. PERLOFF, MODERN INDUSTRIAL ORGANIZATION 532-40 (3d ed. 2000); JEFFREY CHURCH \& ROGER WARE, INDUSTRIAL ORGANIZATION: A STRATEGIC APPROACH 582-88 (2000); Jennifer F. Reinganum, The Timing of Innovation: Research, Development, and Diffusion, in 1 HANDBOOK OF INDUSTRIAL ORGANIZATION 850 (Richard Schmalensee \& Robert D. Willig eds., 5th ed. 1998); Gideon Parchomovsky, Publish or Perish, 98 MICH. L. REV. 926 (2000).

104 See CHURCH \& WARE, supra note 103, at 584. This is to be distinguished from a commercial advertising campaign in which parties divide the market. The absence of a private return may spell the end of the business. There may, however, be a public return to the competition in the form of faster and more thorough news reporting. 
On the other hand, the winner-take-all aspect of the race may ultimately be beneficial and inseparable from an effective hot news policy. Without the competition, news may not be discovered as quickly as it otherwise would be. Indeed, competition is a driving force in the news industry, where rivals thrive on being the first to publish the news. It is hard to imagine a policy that does not maintain this race and, thus, the inevitable duplication of efforts. However, one can reverse this logic and view the cost of competition not as a waste but as a necessary sacrifice for having news gathered aggressively and reported promptly.

It is also possible that hot news exclusivity could stifle the flow of information. In the context of musical compositions, for example, there is evidence that the lack of copyright actually increased productivity as artists could not rely on law to protect their income flow. ${ }^{105}$ Once copyright was available, so the argument goes, the need to produce became less urgent. The same may be the case with hot news. The lack of protection helps create the constant pressure to uncover new facts. Consequently, it must at least be acknowledged that hot news exclusivity could reduce the incentive to invest in news gathering and reporting. While this is, of course, an empirical question that may not be possible to answer, it does suggest that costs could be incurred if the period of exclusivity is too long.

On a more obvious level, the process of gathering and disseminating news has benefits and costs. There are costs associated with the fact that winners of the news race will have exclusivity, and thus others will be prevented from reporting the news or they will be required to pay for the right. In effect, during the period of exclusivity, those with rights to the news may be able to charge monopoly prices for access. Some may pay and some may go without the news, although it would beneficial for them to have access. There is also the cost of administering the system itself. Although it makes sense to think in term of optimal levels of hot news, both costs and benefits are difficult if not impossible to quantify. 106

The matter of costs also raises the issue of whether hot news rights can be assigned to those who produce it at the lowest cost. In short, if the policy is to grant a temporary monopoly to individual entities, it would make sense to bestow the right to those entities that produce at

105 See Denis Borges Barbosa, On Artefacts and Middlemen: A Musician's Note on the Economics of Copyright, 4 INT'L J. OF INTELL. PROP. MGMT. 23 (2010).

106 As noted earlier, these costs and benefits may be monetized or not. See supra note 5. Economists put this idea in terms of marginal analysis. They compare the additional cost of another unit of information with its benefit. Once the marginal cost exceeds the marginal benefit, society is actually worse off since the value of information is less than its cost to create. For and analogous analysis in the context of copyright, see Jeffrey L. Harrison, $A$ Positive Externalities Approach to Copyright Law: Theory and Application, 13 J. INTELL. Prop. L. 1 (2005). 
the lowest cost. At the extreme and fanciful level, one could imagine an auction with competitors bidding on the right to invest in the discovery of information. Their bids are in the form of the amount of time that exclusivity would be required. The lowest bidder-the firm that can remain in the news gathering business with the shortest length of exclusivity-would likely be the most efficient. This is, of course, unrealistic but it is useful to keep in mind that another cost of an extensive period of exclusivity may be to support inefficient news gatherers.

\section{What News Is Protected?}

Given that the protection of hot news will require a public investment, the question arises whether all news should be protected. In a cost-free context, almost certainly the answer is yes. However in a public investment context, three issues present themselves. First, in theory, facts already exist and are simply discovered. The ideal hot news policy would encourage the discovery of pre-existing facts that would not be uncovered and disseminated but for the promise of exclusivity. On the other hand, the ideal policy should not encourage the staging of events leading to facts that would not be created but for the exclusivity. ${ }^{107}$ This second category could range from a reporter deliberately putting a private party in an unrealistic situation and then reporting the outcome as "news" to setting fire to a building and covering the inferno as news. This exclusion would not extend to bona fide investigative reporting. There is no doubt all information resulting from these contexts is still news, and from an absolutist and cost-free perspective, it should be protected. Moreover, controls would still exist. Reporters and their employers are subject to legal action associated with overzealous efforts. Still, it is legitimate to question whether a hot news policy should (or even can) be designed to exclude news that is more or less manufactured to have a product to sell. Seen in a different light, does it make sense to require the public to subsidize this kind of news?

Second, news can be made to seem significant or even lifechanging depending on how it is reported or whether it is presented at all. Insignificant information may be presented with a great deal of dramatic effect to convince the reader that it is of greater consequence than it is. In a sense, reporters choose what is news worthy. "News worthy" likely involves commercial decisions about what stories will draw the greatest readership. Since a public investment is involved, it is important not to confuse facts with their packaging or the commercial

107 This is not to say this news would cease to exist. It likely has commercial value and even without exclusivity the market may produce it. 
appeal. In a sense, the news should speak for itself. Moreover, packaging already is protected by copyright and private agreements.

Third, and aside from creating news and issues of packaging, is the question of qualitative distinctions among facts. In short, some news may be more deserving of protection than other news.108 Put starkly, does news about the latest Kardashian marriage or divorce warrant a public investment as hot news? In copyright, qualitative distinctions technically are forbidden, as it would mean differentiating between supposedly good art and bad art.109 Yet an optimal hot news policy would allow some kind of distinction. This obviously would not be deciding what is "good" news and "bad" news. Instead, the line distinguishes news that makes a difference from that which does not. This distinction is partly captured by the difference, discussed above, between creating news and finding news but this does not fully describe the concept. The difference is closer to that between news for entertainment that has no long-term impact on one's well-being or understanding of his or her environment and that which does have longer run implications. Admittedly, the line is hard to draw. Most would probably agree that knowing the latest rumor about a Hollywood celebrity's divorce may be interesting, but this type of information, at best, is simply entertainment. On the other hand, research and reporting about the plight of the Euro can make one a more informed member of the public. As will be discussed later, it is possible that this question can be resolved by recognizing that much entertainment news is fungible 110 and rarely in short supply. ${ }^{111}$

\section{Can the Hot News Period of Exclusivity Be Varied?}

Another problem is that not all news requires the same level of investment to be discovered and reported. In fact, some requires no effort at all. In the NBA v. Motorola case, anyone viewing the games would know the scores, regardless of whether they had any interest in reporting them to others. Granting a single news gatherer an exclusive right to easily found information creates something of a windfall. The distinction here is similar to contract theory and the duty to disclose

108 Although it is bedrock copyright law that courts do not make decisions about the aesthetic merits of works, this is not always the case. See Jeffrey L. Harrison, Rationalizing the Allocative/Distributive Relationship in Copyright, 32 HOFSTRA L. REV. 853, 889-90 (2004).

109 See Campbell v. Acuff-Rose Music, Inc., 510 U.S. 569 (1994); Bleistein v. Donaldson Lithographing Co., 188 U.S. 239 (1904).

110 The analysis here is comparable to what economists label monopolistic competition. Each entertainment story will be slightly different, meaning there is a fleeting commercial attraction. See id. at 854-55.

111 See discussion infra Part V. 
information. The consensus there, based on a theory first advanced by Anthony Kronman, 112 is that information obtained by one party through investment in research need not be disclosed. Requiring disclosure would prevent the industrious person from internalizing the gains made possible by his or her research efforts. Thus, a geologist investigating the location of oil reserves would have little incentive to incur the costs that would bring a valuable resource to market. On the other hand, disclosure of casually acquired information would not have a similar impact. ${ }^{113}$ Its discovery is not based on an expected profit.

The same holds true for hot news. The more difficult it is to find, the greater the necessary incentive. Even in copyright, this principle is implicitly recognized. Doctrines such as "thin copyright," 114 de minimis copying, 115 and fair use 116 can be used to avoid creating a windfall for those who are actually offering little in exchange for copyright protection. ${ }^{117}$ When applied to hot news, these tendencies support a policy that extends exclusivity only to news that would not exist but for some level of exclusivity and extends greater exclusivity for news that requires more effort to uncover. The first part of this standard is relatively easy to administer. The second is much more complicated.

The issues of what news to protect and varying levels of exclusivity cannot be separated from cost considerations. An expansive definition of what is protected raises the number of incidents in which exclusivity is expected and, thus, the number of instances in which it may be contested. Yet a more discerning approach that narrows the scope and varies the levels of protection has its own problems. The resulting uncertainty can also raise the cost of administering the system.

\section{E. Seepage and Internalization}

To be effective, a hot news policy must address free riding in a meaningful way. The idea is to control seepage that would undercut the incentives of the hot news gatherer. Consequently, it is important to note the free riders in the hot news scenario are competitors. Although

112 Anthony T. Kronman, Mistake, Disclosure, Information, and the Law of Contracts, $7 \mathrm{~J}$. LEGAL STUD. 1, 2 (1978) (arguing that deliberately acquired information should enjoy a right to nondisclosure in contract law). But see Jeffrey L. Harrison, Rethinking Mistake and Nondisclosure in Contract Law, 17 GEO. MASON L. REV. 335 (2010).

113 Kronman, supra note 112 , at 2, 13.

114 See, e.g., Sandava v. Lowdery, 323 F.3d 805 (9th Cir. 2003).

115 See, e.g., Newton v. Diamond, 349 F.3d 591 (9th Cir. 2003).

116 See, e.g., Campbell v. Acuff-Rose Music Inc., 510 U.S. 569 (1994).

117 In fact, although unsuccessful, there have been calls in copyright to lessen protection for works the market would produce without the help of copyright law. See Harrison, supra note 108, at 856-57; Joseph Scott Miller, Hoisting Originality, 31 CARDOzO L. REV. 451, 456-57 (2009). 
copyright law has a similar theme in the context of a fair use analysis, 118 the overall approach to hot news is quite different. The creator of a copyrighted work internalizes the benefits by selling copies of the work or licensing others to make use of the work. Thus, even a downloader without any intention of reselling the work is interfering with the artist's internalization. In the case of hot news, a news organization's revenue is largely decided by the size of its audience. Consequently, hot news producers generally favor greater access to their information. The harmful seepage occurs not when the news is read or even downloaded but when others take the news and disseminate it on a different platform, diverting audience from the original source of the information. A final note on the issue of seepage is that it is almost certainly independent of politically drawn borders.

\section{F. A Hot News Policy: Preliminary Formulation}

A system that balances these cost and benefits defines hot news functionally and then protects it for a limited period from use by a wide spectrum of potential free riders who are also competitors. This almost certainly rules out a state-by-state approach with varying levels of protection for different periods of time depending on the state or even no protection at all. To be sure, much news is local but even that does not mean it is state specific with respect to its importance.119 The obvious analogy here again is to copyright law. The knowledge that one's efforts are only protected in some areas reduces incentives to create. In addition, different jurisdictions with varied standards creates a lack of uniformity that increases the risk of misunderstanding and the likelihood of litigation. ${ }^{120}$

In sum, an ideal system is one that is uniform from state to state and provides various levels of protection to low-cost suppliers of socially relevant news that would not be reported but for exclusivity. The ideal is likely unobtainable. Efforts to vary protection on the basis of the investment would be expensive and create uncertainty. Administrative costs may offset any benefits of such an approach. On the other hand, a set period of exclusivity will overprotect some gathering and reporting efforts while under protecting others. Distinguishing "socially relevant" news from frivolous news is similarly difficult, but here, the risks might actually be acceptable. The uncertainty could incentivize news

118 However, market effects are just one element of a fair use test. 17 U.S.C. $\$ 107$ (2012).

119 More importantly, the positive external effects of reporting may be felt outside local areas.

120 Uncertainty about the law increases risks and can increase the incidence of litigation. George L. Priest \& Benjamin Klein, The Selection of Disputes for Litigation, 13 J. LEGAL STUD. 1, 45 (1984). 
organizations to focus on information that is a relatively safe bet for being viewed as useful-such as public-interest journalism, investigative reporting, and arts and cultural coverage. A final problem is the distinction between rewarding the creation of events that result in "news" and rewarding the discovery of facts through painstaking effort. As opposed to questions of practicality, the decision here may be based more on one's personal beliefs. An absolutist approach would protect news in both categories, while a more functional approach would narrow the protection to the latter types of news.

\section{Hot News Proposals EXPLORED By the FTC}

In its consideration of hot news, the FTC concentrated on three proposals. One would be to encourage expanded state protection of hot news. A second approach would be to abolish all state causes of action and to amend the Copyright Act to include hot news. Finally, the possibility most consistent with a hot new policy as described here would involve an independent federal statute preempting state law.

\section{A. Encourage More States to Adopt Hot News}

The FTC proposal to encourage more states to view free riding as a form of misappropriation begins with amending the Copyright Act so that the treatment of hot news is not preempted by the Copyright Law. ${ }^{121}$ Specifically, this would be accomplished by amending section 301 of the Act, which already delineates four instances in which state law is permitted to operate despite its similarity to copyright. ${ }^{122} \mathrm{~A}$ fifth category would be added to the list: hot news misappropriation. ${ }^{123}$ The premise is that express clarification would push courts to embrace the exclusivity doctrine. ${ }^{124}$

121 FTC DISCUSSION DRAFT, supra note 99, at 9-10.

12217 U.S.C. $\$ 301$. For example, the exceptions include protecting the architectural design of state historical landmarks and protecting works that are not fixed in a tangible medium of expression, such as a poem that is only recited orally and never recorded or written down. In these instances, states are free to provide their own legal safeguards without fearing preemption by federal copyright law. Id. For a discussion of section 301 and its complexity, see CRAIG JOYCE ET AL., COPYRIGHT LAW 958-61 (8th Cir. 2010).

123 Current copyright law withholds copyright protection from facts. It is also broadly preemptive. One could argue that the protection of facts in any form by state law would run afoul of this preemption because prohibiting misappropriation would be comparable to affording copyright protection. Thus, the proposed amendment would clarify the matter.

124 See generally Marburger \& Marburger, supra note 8. The Marburgers suggests that section 301 of the Copyright Act should be amended to say, in substance, that " $t$ ] Act does not preempt statutory or common law unfair competition or remedy for unjust enrichment, regardless of whether a contested publication infringes copyright." Id. at 46 
The chief advantage of this approach is that it gives states flexibility to fashion a hot news remedy to their individual likings, creating a diverse and responsive body of law. ${ }^{125}$ A preemptive problem with this approach is that Congress expressly rejected an initial plan to add hot news misappropriation to section 301 during debate on the 1976 amendments to the Copyright Act. ${ }^{126}$ Observers say Congress is not apt to adopt a different position today, though that view may be out-oftouch with recent developments. ${ }^{127}$ In any event, an early draft of the 1976 revisions included a hot news misappropriation provision in the amended section $301.128 \mathrm{~A}$ corresponding House report explained that "state law should have the flexibility" to provide a remedy for "unauthorized appropriation by a competitor of the facts (i.e. not the literary expression) constituting 'hot' news." 129 Yet this version ultimately was rejected. 130 The legislative history shows it ran into trouble when members of Congress, most notably U.S. Rep. John F. Seiberling, an Ohio Democrat, cautioned that a hot news exception would imply that states had free reign to experiment with the doctrine. ${ }^{131}$ Seiberling contended that such excessive flexibility would "render the preemption section meaningless."132 Thus, the hot news exception was dropped out of fear that states would misapply the carefully circumscribed doctrine. ${ }^{133}$

Even with an express preemption, there are additional uncertainties. First, how many states would adopt a hot news policy? Second, would their approaches conform to the ideal described above? It is the case that some courts do appear reluctant to provide hot news protection under the assumption that these claims usually are

(emphasis added) (internal quotation marks omitted). For more on the Marburgers' view of the preemption problem, see $i d$. at $46-50$.

125 Id.

126 Shane M. McGee, Cooling Off the Hot-News Exception: National Basketball Ass'n v. Motorola, Inc., 66 U. CIN. L. REv. 1019, 1037-38 (1998) (describing the debate over section 301 during the amendment process).

127 Given the government's recent interest in the media's downturn, it is not entirely clear that Congress would be unwilling to amend section 301 to accommodate hot news. See supra note 98 and accompanying text.

128 See Gregory, supra note 1, at 595 (describing the legislative history of the 1976 amendments to section 301).

129 H.R. REP. No. 94-1476, at 132, (1976), reprinted in 1976 U.S.C.C.A.N. 5659, 5748 (discussing whether hot news should remain in the "mold" of International News Service $v$. Associated Press or take a "newer form").

130 See 17 U.S.C. $\$ 301$ (b) (2012) (providing four exceptions to preemption that do not include hot news misappropriation).

131122 CONG. REC. 32,015 (1976) (statement of Rep. Seiberling) [hereinafter Statement of Rep. Seiberling]. Seiberling died in 2008, having served in Congress from 1970 to 1986, when he chose not to run for reelection. See Bob Downing, John Seiberling Is Dead at 89, AKRON BEACON J., (Aug. 2, 2008), http://www.ohio.com/news/john-seiberling-is-dead-at-89-1.121949.

132 Statement of Rep. Seiberling, supra note 131.

133 Gregory, supra note 1, at 607. 
preempted by federal law. ${ }^{134}$ For example, a federal district court in Maryland held in 2010 that when the allegedly misappropriated information went beyond "mere facts" to include copyrightable material, then copyright law preempted the hot news claim.135 The rationale for this is not clear. If facts are not copyrightable, their presence within copyrightable material does not address the issue of whether they might be protected by separate state or federal law.

Some who argue for a state-by-state solution say the problem is that courts miss the nuances of hot news misappropriation, which veers from the straight-up copying that underlies copyright protection. ${ }^{136}$ As described above, hot news hinges on gaining a competitive advantage; whereas the average copyright infringer has no business motive as he or she, say, downloads a protected movie or song from a website for personal enjoyment. If an amended Copyright Act can help courts overcome their reluctance, so the argument goes, state judges could build a malleable body of hot news law that would bend with future technological developments. Whether clarification of the preemption issue and a better understanding of hot news interests as opposed to copyright interests would actually advance the development of state law is, of course, an empirical question. Moreover, there is nothing in these suppositions that addresses the second problem-would there be uniformity?

The second problem is actually an outgrowth of the very flexibility that makes it attractive to some and easily outweighs any advantages. This is easy to understand by thinking in terms of fifty state legislature or courts experimenting with a variety of approaches to a problem that

134 The Third Circuit has bemoaned the lack of guidance on preemption, noting that the U.S. Supreme Court has not "clearly defined where the power of the states to protect interests in intellectual property ends, and where the realm of federal preemption begins." U.S. Golf Ass'n v. St. Andrews Sys., 749 F.2d 1028, 1036 (3d Cir. 1984); see also Agora Fin., LLC v. Samler, 725 F. Supp. 2d 491, 500-01 (finding that a misappropriation claim in Maryland was preempted by copyright law).

135 See Agora Fin., 725 F. Supp. 2d at 501 (noting that original works "are copyrightable and, therefore, not subject to protection under the NBA court's formulation of the INS doctrine"); see also Rod S. Berman, Some Like It Hot: Digital Technology Has Raised Questions About the Reach of the Tort of the Misappropriation of Hot News, L.A. LAW., Dec. 2010, at 20, 23 (discussing Agora Financial, LLC $v$. Samler while explaining the preemption problem with hot news misappropriation).

136 Gregory, supra note 1, at 596. As Gregory warns, courts often view both claims through the same lens:

In other words, misappropriation--stealing from a competitor to get ahead in business-is distinct from the generalized bad-faith taking that copyright law prohibits, and is not, therefore, preempted by copyright law. Only where litigants frame misappropriation in terms of "amorphous concepts such as 'commercial immorality' or society's 'ethics" does preemption become an issue, because "[s]uch concepts are virtually synonymous for wrongful copying and are in no meaningful fashion distinguishable from infringement of a copyright."

Id. (alteration in original) (quoting NBA v. Motorola, 105 F.3d 841, 853 (2d Cir. 1997)). 
has little to do with geographic borders. Two specific dangers are particularly glaring. First, the media would be forced to invest considerable time and money litigating on a state-by-state basis. ${ }^{137}$ News organizations would have to wait for cases with the perfect facts138 facts that would meet the requirements of hot news and therefore keep the claim from being preempted.139 After finding a good candidate, however, there would be no guarantees. While an amended section 301 may assuage concerns about preemption, courts still could view the doctrine itself as suspect.140 Judges may reject hot news as an inappropriate extension of property rights, ${ }^{141}$ or punt to the legislature, claiming that state lawmakers should address the issue.142 Justice Brandeis suggested that course in his influential dissent ${ }^{143}$ in the INS case, complaining that courts were "ill-equipped to make the investigation [into]... the limitations which should be set upon any property right in news." 144

Second, at the end of the day, there will be no uniformity to ensure predictable outcomes and protection across jurisdictions. This last criticism recognizes that a necessary element of any hot news policy is the avoidance of seepage. Without that guarantee, overcoming all of the previously discussed problems would not do much to solve the problem. Even if the media start winning hot news cases in more states, the result could be a "sloppy, patch-like quilt" 145 of protection that is inconsistent and largely unattainable. ${ }^{146}$ Hot news litigation will remain rare. Media

137 Bruce W. Sanford, Bruce D. Brown \& Laurie A. Babinski, Saving Journalism with Copyright Reform and the Doctrine of Hot News, COMM. LAW, Dec. 2009, at 8, 9-10 (explaining how the hot news doctrine may help the media curb free riding by competitors).

$138 I d$. at 10 (noting that the cases would "have to be carefully chosen so that the facts reflect inequities so fundamental that courts are prompted to look outside of recognized law for a remedy").

139 See Barclays II, 650 F.3d 876, 900 (2d Cir. 2011) (describing three elements required to establish a hot news claim).

140 See generally Bruce P. Keller, Condemned to Repeat the Past: The Reemergence of Misappropriation and Other Common Law Theories of Protection for Intellectual Property, 11 HARV. J.L. \& TECH. 401 (1998) (arguing against the creation of a statutory hot news tort); Richard Posner, Misappropriation: A Dirge, 40 HoUs. L. REV. 621, 621 (2003).

141 Douglas G. Baird, Common Law Intellectual Property and the Legacy of International News Service v. Associated Press, 50 U. CHI. L. REV. 411, 415-23 (1983) (describing criticisms of the hot news doctrine from the bench, including concerns of Second Circuit Judges Learned Hand and Charles Edward Clark).

142 Int'l News Serv. v. Associated Press, 248 U.S. 215, 264-67 (1918) (Brandeis, J., dissenting).

143 Wendy J. Gordon, On Owning Information: Intellectual Property and the Restitutionary Impulse, 78 VA. L. REV. 149, 272-74 (1992) (discussing Brandeis' dissent).

144 Int'l News Serv., 248 U.S. at 267 (Brandeis, J., dissenting).

145 John Tessensohn, The Devil's in the Details: The Quest for Legal Protection of Computer Databases and the Collections of Information Act, H.R. 2652, 38 IDEA 439, 464 (1998) (asserting that state misappropriation law does not provide adequate protection for computer databases).

146 See, e.g., Barclays II, 650 F.3d 876 (2d Cir. 2011) (creating stringent criteria for hot news claims). 
will seek redress in states that have the most lenient approach to hot news, but only when the state can establish jurisdiction over the defendant. In the end, the lack of uniformity gives little guidance to bloggers, news aggregators, and anyone who wants to lift the facts from a juicy piece of hot news. ${ }^{147}$ Moreover, the FTC points out that there are many undeveloped areas of hot news jurisprudence. 148 Courts cannot decide how long hot news protection should last, or whether direct competition between plaintiffs and defendants is an absolute requirement, and if so, to what degree the parties must directly compete. Different states will resolve these issues in varying ways, hobbling any coherent effort by the media to protect its newsgathering. Hence, practical concerns about the inefficiencies of state-by-state litigation, as well as the resulting inconsistencies counsel against this FTC proposal to strengthen the common law tort.

\section{B. Abolish the Common Law Tort and Add Hot News to the Existing Copyright Act}

A second proposal calls for abolishing common law misappropriation and amending the Copyright Act to protect hot news in some fashion. ${ }^{149}$ This idea might appease some who challenge the very legitimacy of a misappropriation approach, such as the authors of the Restatement (Third) of Unfair Competition 150 and iconic Judge Richard Posner of the Seventh Circuit, who once mused that misappropriation "can be jettisoned, so far as intellectual property is concerned at any rate, without loss." 151 These critics claim that the doctrine is more hazardous than helpful because it can be applied without clear limits and in cases that are rightfully rejected by other areas of law (such as copyright).152 But aside from making its detractors happy, there are three reasons why abolishment of the state cause of action may be advantageous: First, at least some forms ${ }^{153}$ of a hot news doctrine may violate the First Amendment; second, the doctrine is untenable in today's internet-based world; and third, it requires a

147 Gregory, supra note 1 , at 610 (expressing dismay that courts will not judge misappropriation claims "consistently across jurisdictions").

148 FTC DISCUSSION DRAFT, supra note 99 , at 9.

149 Id. at 9-10.

150 The Restatement calls for misappropriation's abolishment and concludes "[t]he better approach... does not recognize a residual common law tort of misappropriation." RESTATEMENT (THIRD) OF UNFAIR COMPETITION $\$ 38 \mathrm{cmt}$. b (1995).

151 Posner, supra note 140 , at 621.

152 Id. at 638 ("Misappropriation doctrine ... is alarmingly fuzzy once the extreme position of creating a legal right against all free riding is rejected, as it must be.").

153 Presumably forms would vary from state to state, potentially meaning a series of First Amendment challenges. 
complex preemption analysis that the courts keep changing-or perhaps botching in their applications. Of course, even if these are true advantages they must be balanced against the effectiveness of a hot news addition to the Copyright Act.

Google articulated the First Amendment argument in its written comments for the FTC workshops on journalism's survival. 154 In asserting that the hot news doctrine violates free speech, Google noted that sharing truthful information is "one of the most closely guarded forms of speech under the Constitution" and suggested that hot news is not sufficiently important to override the First Amendment.155 As an example of the potential danger to free speech, recall that during his first presidential campaign, then-Senator Obama talked at a San Francisco fundraiser about "bitter" small-town voters who "cling to guns and religion." 156 A woman who was blogging about the event recorded the remarks. ${ }^{157}$ She later reported Obama's comments, 158 which became the focus of a national media frenzy. Under a poorly drafted hot news policy, it is possible that she could have kept others from reporting on the future president's statements. 159 Critics certainly can argue that, unless carefully constructed, hot news would prevent-or at least delay-the type of vetting that is only possible by a firestorm of media seeking clarification. 160

154 GOOGLE, COMMENTS ON FEDERAL. TRADE COMMISSION's NEWS MEDIA WORKSHOP AND STAFF DISCUSSION DRAFT ON "POTENTIAL POLICY RECOMMENDATIONS TO SUPPORT THE REINVENTION OF JOURNALISM" 17 (2010), available at http://static.googleusercontent.com/ external_content/untrusted_dlcp/www.google.com/en/us/googleblogs/pdfs/google_ftc_news_ media_comments.pdf.

155 Id. Google's free speech concerns are shared by the Electronic Frontier Foundation, which warns that the hot news doctrine could be "used to quash online commentary and information-sharing." Press Release, Electronic Frontier Found., "Hot News" Doctrine Could Stifle Online Commentary and Criticism (June 22, 2010), available at http://www.eff.org/press/ archives $/ 2010 / 06 / 22$.

156 Calvert et al., supra note 1 , at 22.

157 Id.

158 Id.

159 The blogger, Mayhill Fowler, waited four days before reporting the remarks on OffTheBus.net, a website published by the Huffington Post. An Obama supporter, Fowler initially was reluctant to publicize the comments but said that she ultimately felt obligated to do so. See Katharine Q. Seelye, Blogger Is Surprised by Uproar over Obama Story, but Not Bitter, N.Y. TIMES, Apr. 14, 2008, http://www.nytimes.com/2008/04/14/us/politics/14web-seelye.html (describing how Fowler was under attack because the event had been closed to the press). However, under the hot news policy proposed in Part V, infra, hot news protection would have been inapplicable in this case since the news was causally acquired and was not promptly reported.

160 In International News Service v. Associated Press, Justice Brandeis penned a thoughtful dissent that emphasized the First Amendment implications of creating a quasi-property right in news. He warned that " $[t]$ he general rule of law is, that the noblest of human productionsknowledge, truths ascertained, conceptions, and ideas-become, after voluntary communication to others, free as the air to common use." Int'l News Serv. v. Associated Press, 248 U.S. 215, 250 (1918) (Brandeis, J., dissenting). 
If the First Amendment alone does not justify abolishing hot news and placing it with the realm of copyright, the doctrine's critics also stress the impracticality of enforcing any right to time-sensitive information. Dozens of observers may be pressed along the fluorescent tape at the edge of a crime scene. Any of them can take out their cell phones and capture events. Who should have the hot news rights? As Google and Twitter have argued jointly, the realities of the Internet age ensure that news is disseminated as it is occurs. ${ }^{161}$ The Internet giants claim that "the notion that a single media outlet should have a monopoly on time-sensitive facts is not only contrary to law, it is, as a practical matter, futile." 162

Lastly, those who support abolishing the doctrine argue that the complicated preemption analysis in hot news cases leads to significant unpredictability. ${ }^{163}$ There is no consensus on the best test for identifying claims that do not clash with the Copyright Act. Even the Second Circuit, which has led the way in hot news jurisprudence, cannot seem to commit to one framework. 164 Moreover, outcomes still vary when courts use the same test-even under strikingly similar facts. ${ }^{165}$ As such, the media already have little incentive to rely on the doctrine, as the "mere threat of federal preemption and the extra steps ... required to avoid it are likely to give pause to any news organization considering a state-law misappropriation action."166 Thus detractors legitimately may assert that eliminating the tort would cause little backlash. Both the instability and difficulty in evaluating preemption argue in favor of the FTC's first proposal to abolish hot news misappropriation. This argument has some validity but adoption presupposes that a better alternative is unavailable that would address the same problem, as discussed below.

These arguments in favor of abolishing a state-by-state approach have some merit but perhaps the principal appeal is avoidance of state by state differences and the uncertainty created. The second element of this approach is to amend the Copyright Act to include hot news as a

161 Brief for Amici Curiae Google Inc. \& Twitter, Inc. in Support of Reversal at 3-4, Barclays II, 650 F.3d 876 (2d Cir. 2010) (No. 10-1372-cv) 2010 WL 2589770 [hereinafter Amici Brief].

$162 \mathrm{Id}$. at 4. Under a properly drawn hot news policy, as described infra Part V, this news would not be protected as long as each reporter acted independently.

163 See Schmidt, supra note 1, at 330-32 (pointing to Scranton Times, L.P. v. Wilkes-Barre Publ'g Co., No. 3:08-cv-2135, 2009 WL 585502 (M.D. Pa. Mar. 6, 2009), as an example of the unpredictable application of the hot news doctrine).

164 In NBA v. Motorola in 1997, the Second Circuit described a five-element test for hot news plaintiffs to avoid preemption by the Copyright Act. 105 F.3d 841, 845 (2d Cir. 1997). Then in 2011, the Second Circuit tinkered with the NBA test, creating a three-element analysis in Barclays II. See 650 F.3d 876, 900 (2d Cir. 2011).

165 See supra note 95.

166 Schmidt, supra note 1 , at 333. 
protected category. ${ }^{167}$ Several ideas are percolating on the best way to stretch copyright to cover hot news. 168 One is to add a provision with a multi-prong test for protecting information under circumstances closely resembling the facts in International News Service v. Associated Press. 169 In this vein, Google and Twitter have suggested a test that requires plaintiffs to meet a whopping eight elements. ${ }^{170}$ Their test focuses on the nature of the information at issue, requiring it to be released only to a "restricted audience" and not the general public; to have commercial value; and to have been unearthed exclusively by the plaintiff. ${ }^{171}$ Others eschew complicated analyses and suggest a blanket approach. For example, the Copyright Act could be amended to give hot news twentyfour hours of protection following its release.172 The temporary

167 FTC DISCUSSION DRAFT, supra note 99, at 9-10. The first proposal has two components: 1) abolish the common law tort, and 2) amend the Copyright Act to cover hot news. Id.

168 Two First Amendment attorneys, Daniel Marburger and David Marburger, are vocal proponents of amending the Copyright Act to protect hot news. See David Marburger \& Dan Marburger, Op. Ed., Internet Parasites: Websites Protected by Copyright Law Are Killing Newspapers by Sucking Up Content That Is Gathered at a Hefty Cost, L.A. TIMES, Aug. 2, 2009, at A28 (calling for Congress to address the free-riding problem among media competitors). However, beyond the narrow issue of hot news, there has been a longstanding debate on whether factual information in general should garner copyright protection. See Robert C. Denicola, Copyright in Collections of Facts: A Theory for the Protection of Nonfiction Literary Works, 81 COLUM. L. REV. 516, 519 (1981) (exploring the inconsistent rationales used to address property rights in factual works); Jane C. Ginsburg, Creation and Commercial Value: Copyright Protection of Works of Information, 90 COLUM. L. REV. 1865, 1866 (1990) (critiquing the scope of copyright protection for works that are based on factual information).

169 Amici Brief, supra note 161, at 15-16; see also Gregory, supra note 1, at 604 (explaining how hot news opponents are urging tight constraints if hot news is folded into the Copyright Act).

170 Google and Twitter's complete list of requirements are:

(1) [T] he information plaintiff seeks to protect must have been gathered exclusively by plaintiff (2) at substantial cost or effort; (3) plaintiff must have taken steps to keep the information confidential or highly restricted until its release; (4) plaintiff's release of the information must be to a restricted audience, and not be accessible to the general public; (5) the information must have commercial value; (6) the information must be time-sensitive, and defendant's use of the information must specifically exploit its time-sensitive nature; (7) plaintiff and defendant must be direct competitors for the commercial value of the particular information in question; and (8) as a direct result of defendant's use of the time-sensitive information, plaintiff s ability to produce the product or service will be severely impaired.

Amici Brief, supra note 161, at 15-16.

171 Id.

172 Ryan T. Holte, Restricting Fair Use to Save the News: A Proposed Change in Copyright Law to Bring More Profit to News Reporting, 13 J. TECH. L. \& POL'Y 1, 32-33 (2008). Holte recommends amending the Copyright Act's fair use provision, section 107, which provides a defense to what would otherwise be actionable copyright infringement. See 17 U.S.C. \$107 (2012). Section 107 expressly lists "news reporting" as a type of fair use, along with criticism, commentary, scholarship, and research. In suggesting a blanket, twenty-four-hour window of protection for hot news, Holte explains that the provision would include these key points:

(1) the protection would not extend to traditional news headlines-to allow third parties the ability to advertise a competitor's story and link to it; (2) the protection 
exclusivity would allow news organizations to profit from their costly reporting while ultimately ensuring that anyone can use the factual information. ${ }^{173}$

Although the general substance of these proposals makes sense, the idea of including hot news within the Copyright Act involves a high degree of shoehorning and, to some extent, a misunderstanding of the differences between protecting creative efforts and protecting the finding and reporting of facts. It is not as simple as adding hot news to the list of protected "works." Instead, this approach would attempt to merge two fundamentally different pieces of legislation. For example, the Copyright Act's anchor is a definition of what works are protected 174 and the exclusive rights of authors. ${ }^{175}$ Complex statutory language is devoted to duration of copyright 176 and the termination rights of authors. ${ }^{177}$ None of this material would be relevant to hot news. In fact, it is difficult to find portions of the Copyright Act that would apply to hot news. Perhaps the lone similarity between hot news and copyright is the goal of avoiding free riding but that does not distinguish either one from other property rights. ${ }^{178}$ In addition, as already noted, the type of free riding to be avoided differs between copyrighted works and hot news. ${ }^{179}$

Moreover, there is no indication that Congress would undertake such a revision. On three prior occasions, Congress has failed to act on proposed laws that would protect factual information within databases. 180 There is no reason to believe that Congress would be more

would only last for twenty-four hours-so that after a reporter has realized a profit in his story, the story could subsequently be reproduced freely to allow the dissemination of ideas; and (3) the reporter's rights in the story could not be used to restrict a purely nonprofit organization from posting the story.

Id. at 33; see also 17 U.S.C. $\$ 107$ (stating that fair use should be evaluated under four factors: 1) "purpose and character of the use"; 2) "nature of the copyrighted work"; 3) "amount and substantiality" of the copyrighted material that was used; and 4) economic impact on the value of the original, as well as its impact on the ability of the rights' holder to license derivatives).

173 Holte, supra note 172 , at 33 .

17417 U.S.C. $\$ 102$.

175 Id. $\$ 106$.

176 Id. $\$ 304$.

177 Id. $\$ \$ 203,304$.

178 For a classic discussion of why new property rights develop, see Harold Demsetz, Toward a Theory of Property Rights, 57 AM. ECON. REV. 347 (1967) (arguing that property rights emerge when the benefits of having the rights exceed the costs of attaining them). Demestz's theory has been the subject of intense scrutiny and criticism. See, e.g., James E. Krier, Evolutionary Theory and the Origin of Property Rights, 95 CORNELL L. REV. 139, 139 (2009) (analyzing Demestz's theory and postulating that property rights can be explained by evolutionary biology). For another view, see Mark A. Lemley, Property, Intellectual Property, and Free Riding, 83 TEX. L. REV. 1031, 1033-46 (2005) (discussing how the desire to stop free riding is shaping property rights in patents, trademarks, and other areas of intellectual property law).

179 See supra text accompanying notes 114-117.

180 Congress's reluctance to protect factual information will be discussed in more detail. See infra Part IV.C. 
agreeable to the factual nature of hot news. 181 Therefore, both the difficulty of drafting workable statutory protection and the philosophical mismatch are strong arguments against the FTC's proposal to abolish the tort and add hot news protection to the Copyright Act.

\section{Federal Legislation}

The FTC's third proposal suggests enacting a federal law that codifies hot news misappropriation, thereby replacing the common law doctrine by federal preemption. There are substantial advantages to this tact, along with potential disadvantages. The main benefit is that a federal law imposes a uniform, national framework for hot news misappropriation and thus avoids the risks and expense of varying state common or statutory laws. In drafting the new law, Congress could throw its considerable weight and resources into investigating the options, creating legislation that balances the competing interests of the public, news organizations, and Internet kingpins such as Google and Twitter. ${ }^{182}$ Of course, there is nothing more naïve than suggesting that the government is the solution to the problem. ${ }^{183}$ Nevertheless, this is preferable to fifty state governments or judicial systems attempting to solve the same problem.

Perhaps most important is that federal legislation has a better chance of combating the free riding problem by foreclosing escape to jurisdictions that do not recognize hot news. To put it in more erudite terms, national legislation might force misappropriators to internalize the externalities of taking someone else's factual information and using it to their competitive advantage. 184 It would do this by recognizing that geographic borders have little relevance when free riding is a bordercrossing exercise. Thus, a national hot news law could force would-be misappropriators to face potential injunctions, damages or both, wherever they are located.

The most formidable problem with this approach is that it has, so far, not gained much traction in Congress. On at least three prior

181 Dale P. Olson, Common Law Misappropriation in the Digital Era, 64 MO. L. REV. 837, 895-900 (1999) (describing Congress's wariness in protecting factual information as it amended the Copyright Act in the mid-1970s).

182 See Rex Y. Fujichaku, The Misappropriation Doctrine in Cyberspace: Protecting the Commercial Value of "Hot New" Information, 20 U. HAW. L. REV. 421 (1998) (arguing that Congress could properly balance the interests of news providers and the public while creating a unified standard in federal hot news legislation).

183 Recall President Ronald Reagan's quip that nine of "the nine most terrifying words in the English language are 'I'm from the government, and I'm here to help." See Dana Milbank, Reagan's New Party, WASH. POST, July 20, 2011, at A17.

184 Fujichaku, supra note 182 , at 426-34. 
occasions, Congress has failed to codify misappropriation, ever bristling at the notion of cloaking factual information in property-like protection. ${ }^{185}$ In the most recent attempt in 2003, the House Report described observed that proposed legislation "defies the parameters articulated by the Supreme Court in the Feist decision. It attempts to rely on the Commerce Clause of the United States Constitution to do what the [Copyright] Clause prohibits." 186 The implication of this statement is that a hot news statute would be regarded as unconstitutional presumably because it applies to information not covered by the Copyright Act. The logic of this view is not obvious. Instead, it merely raises the question of whether the current Copyright Act exhausts the authority of the Copyright Clause of the Constitution. Recent interpretations by the Supreme Court suggest quite strongly that the Court defers to legislative decisions about the Copyright Clause. ${ }^{187}$ Beyond the question of whether the current Copyright Act has been stretched as far as the Copyright Clause allows is the question of whether a federal hot news policy would have an unacceptable impact on First Amendment rights. A related question is whether attribution is an effective and less restrictive way of achieving the desired ends.

\section{First Amendment Concerns}

The FTC's report noted that "it is unclear how to draw the scope of hot news protection broadly enough to provide significant incentive for news gathering, but narrowly enough" to protect legitimate competition and free speech. ${ }^{188}$ Clearly, a widely used hot news doctrine could

185 In 1997, Congress explored but rejected H.R. 2652, The Collections of Information Antipiracy Act. In 1999, Congress considered a revamped version of The Collections of Information Antipiracy Act. H.R. 354, 106th Cong. (1999). It, too, failed. In relevant part, the bill stated:

Any person who extracts, or uses in commerce, all or a substantial part, measured either quantitatively or qualitatively, of a collection of information gathered, organized, or maintained by another person through the investment of substantial monetary of other resources, so as to cause harm to the actual or potential market of that other person... for a product or service that incorporates that collection of information and is... intended to be offered for sale or otherwise in commerce... shall be liable ... for remedies set forth in section 1406 .

Id.

186 See H.R. REP. No. 108-421, pt. 2 (2004) (discussing H.R. 3261, the Database and Collections of Information Misappropriation Act, which incorporated three NBA elements: time-sensitive information; free riding by the defendant; and a threat to the plaintiff's business); see also U.S. CONST. art. I, $\$ 8, \mathrm{cl} .3$ (setting forth the Commerce Clause, which provides that Congress has the power "[t]o regulate Commerce with foreign nations, and among the several States, and with the Indian Tribes").

187 See, e.g., Eldred v. Ashcroft, 537 U.S. 186 (2003).

188 FTC DISCUSSION DRAFT, supra note 99, at 10. The FTC also cautioned against unintended consequences. The fear is that news organizations will become hot news defendants 
impede some speech. But this valid concern does not have to thwart hot news. Rather, the drafters of hot news legislation would need to build First Amendment protection into the law, performing the sort of balancing that occurs any time a measure might affect protected speech. 189 It is an exercise that is neither beyond lawmakers' ability nor an insurmountable threat to hot news. 190 However, the main reason that free speech concerns should not derail the doctrine is that hot news ultimately protects First Amendment values. It does not diminish them.

The All-Headline News case illustrates this point. All-Headline News was taking AP stories that had been posted on the Internet, rewriting them, and transmitting them to its subscribers. In this way, All-Headline News was making money from news content that it did not produce-but only repackaged. ${ }^{191}$ Meanwhile, AP paid the reporters who collected the information and wrote the articles. AP paid the editors who oversaw the journalists and edited their stories. AP paid for the infrastructure-the computers, the software, the offices-where the work came together and ultimately was transmitted on the AP news wire. Accordingly, AP charged its subscribers sufficient rates to support its sprawling operation. In contrast, All-Headline News bore no expense in the newsgathering. ${ }^{192}$ Theoretically, it could charge far less for the same information as AP and still remain profitable. AP has limited recourse in this situation. As long as All-Headline News is rewriting the articles, 193 and not publishing them verbatim, AP cannot sue for copyright infringement because copyright does not cover the factual content of its news reports. If the practice continued, AP subscribers might be tempted to switch to All-Headline News for the same content at lower rates.

It seems hard to prohibit this activity under a free speech rationale. Indeed, without hot news protection, those who are concerned about

themselves because media outlets "routinely borrow from each other." Id. Such a paradoxical outcome would undermine the doctrine's purpose, which is to help the media reap the value of its original reporting. If news organizations start suing each other, their costs will rise because each entity will be forced to re-report every fact.

189 Copyright itself is a limit on the First Amendment. The U.S. Supreme Court repeatedly has made the observation that some restriction on expression is "the inherent and intended effect of every grant of copyright," but that copyright accommodates for the abridgement with, inter alia, the fair use doctrine. See, e.g., Golan v. Holder, 132 S. Ct. 873, 889 (2012) (discussing how copyright necessarily impinges on free speech).

190 The proposal described here is designed to include these safeguards. See infra Part V.

191 Associated Press v. All Headline News Corp., 608 F. Supp. 2d 454, 457-58 (S.D.N.Y. 2009).

192 Its website indicates that All Headline News, now FeedSyndicate, has a permanently credentialed White House reporter. FeedSyndicate Correspondent Receives Permanent Media Credentials, FEEDSYNDICATE (Dec. 9, 2010), http://www.feedsyndicate.com/corp/press.

193 AP also had a claim for copyright infringement. Associated Press, 608 F. Supp. 2d at 45758. Obviously, a hot news misappropriator can circumvent copyright by extracting the facts from a competitor's news story and rewriting the article. 
free speech matters would find there is less to speak about. While the First Amendment protects the spread of news, it surely does not mean to do so at the peril of those who uncover the information in the first place. A news organization should be free to report the facts that it collects, 194 and even compile summaries of articles by others, but the First Amendment should not be a haven for those who boldly pass off another's work as their own. Hot news misappropriation may hamper speech on some level; but the First Amendment fallout would be much greater if AP and similar organizations had to close their doors. ${ }^{195}$ As one journalist-turned-lawyer 196 put it: "[T]he Constitution's First Amendment protections should not be used to destroy news organizations while supporting the abuses of free-riders; to do so would undermine-not advance - the purposes of free speech."197

There are lessons here that can be adapted from Copyright law, which has an equal potential to impede free speech. In that context, the Supreme Court has recognized the importance of balancing temporary restrictions on speech in the interest of promoting expression in the long run. The "idea-expression" distinction and fair use are part of this formula. ${ }^{198}$ In the case of hot news, the critical balancing feature is that a functional approach only protects news that would not otherwise be disseminated and that exclusivity would be for a short period of time. In addition, as in copyright, independent gathering and reporting should be an absolute defense to a hot news lawsuit. 199 One observer notes that a news organization could show independent reporting with evidence of "the differences in content presented," the time lapse between the original report and the defendant's follow-up, and differences in the "identity and number of sources" in the defendant's report.200 Potential misappropriators should be incentivized to do their own reporting. ${ }^{201}$

194 Subject to well-defined constraints on speech. See LYRISSA BARNETT LIDSKY \& R. GEORGE

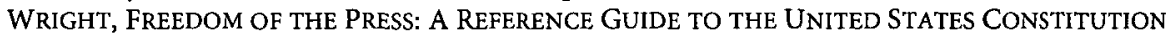
23-56 (2004) (discussing prior restraints, content-based restrictions, and content-neutral regulation of the media).

195 Schmidt, supra note 1 , at 339 ("The danger is that without newspapers and wire services reporting news in the first place, bloggers and aggregators will have nothing to opine about and nothing to feed to other websites.").

196 Brian Westley is a former AP reporter who was based in Washington, D.C.

197 Westley, supra note 84 , at 729.

198 Eldred v. Ashcroft, 537 U.S. 186, 219 (2003).

199 See Westley, supra note 84 , at 728 (asserting that a hot news claim should require the plaintiff to show that the defendant did not independently collect the information).

200 Gregory, supra note 1 , at 611.

201 Id. Allowing this defense provides the motivation. It also addresses the concerns raised by Google and Twitter, which complain that hot news is "futile" in today's internet-based world. Amici Brief, supra note 161, at 3-4. They suggest that no news organization should have the rights to "time-sensitive facts." Id. They are correct in that no entity should be able to enforce hot news rights against a competitor that has cultivated the same facts with its own groundwork. See generally David A. Marcello, The Ethics and Politics of Legislative Drafting, 70 TULANE L. REV. 2437 (1999) (exploring the forces that shape legislative drafting, including the 
Thus, none of the reporters attending a press conference or observing an accident should be able to claim a hot news right even if one of them gets his or her story out first. Moreover, nothing should prevent a news organization from gleaning "tips" from a competitor's publication and going after the story on its own. In neither case is there free riding. All participants make an independent investment.

Indeed, it is a fundamental premise of a free and robust press that the public benefits when multiple organizations turn their energy and resources on exploring a problem or covering events.

\section{The Attribution Alternative}

A subsidiary question that arises when First Amendment concerns are raised is whether attribution would be a less restrictive alternative to exclusivity as a means of achieving the desired outcome. In fact, in Barclays, the Second Circuit suggested that attribution may be sufficient to avoid a hot news claim. ${ }^{202}$ Justice Holmes also made this argument overtly in his INS dissent, asserting that INS' misstep was in using AP's information without giving the Associated Press credit for it.203 The logic of this argument is not obvious. In fact, a federal hot news law should expressly state that attribution is not a defense to a claim of hot news misappropriation. 204 Without this provision, defendants could take the content of the plaintiff 's articles wholesale and still avoid a hot news claim by attributing it to the original source. This is not much different from rewriting articles to avoid copyright infringement. While attribution is courteous, it does nothing to address the unfair competitive conduct at the heart of a hot news claim. 205

\section{Federal Legislation as the Better Alternative}

The best of the three FTC proposals and the most promising means of implementing a functional approach as described here is enactment of federal legislation. Its key advantages are that it does not blur the distinction between copyright and hot news, it does not require any rewriting of the Copyright Act, 206 and it greatly decreases the type of

\footnotetext{
"inescapabl[e]" policy choices that drafters must make).

202 Barclays II, 650 F.3d 876, 903 (2d Cir. 2011).

203 Int'l News Serv. v. Associated Press, 248 U.S. 215, 248 (1918) (Holmes, J., dissenting).

204 Gregory, supra note 1, at 612 (explaining that attribution "does not solve the problem of online news aggregators in today's world").

205 Id.

206 Amy E. Jensen, Comment, When News Doesn't Want to Be Free: Rethinking "Hot News" to Help Counter Free Riding on Newspaper Content Online, 60 EMORY L.J. 537, 556 (2010) (" $[\mathrm{U}]$ sing copyright law to protect facts would conflict with the Act's bedrock principle that
} 
seepage that would almost certainly exist under a state by state approach. A hot news law could be crafted to address the serious, ${ }^{207}$ but ultimately unavoidable, problem of news piracy. Any formulation of hot news must be constrained-targeting only the egregious conduct that creates a competitive advantage for the defendant while whittling away the plaintiff's incentive to uncover the information. Federal legislation has a better chance of discerning and codifying these nuances as Congress churns the proposed legislation through committees, compromise, review, and revision. 208

In drafting a federal hot news law, legislators would do well to reexamine NBA v. Motorola. Most of the Second Circuit's five elements are consistent with the functional approach described here. For example, two elements require the information to be "time-sensitive" and gathered "at a cost." 209 The "cost" requirement is important as a means of separating "news" that is casually as opposed to deliberately discovered. Moreover, the plaintiff and defendant must be in "direct competition" such that the defendant's use of the information "constitutes free riding on the plaintiffs efforts." 210 However, the fifth NBA element creates an unnecessary hurdle that could undermine much of a rational hot news policy. According to the court the free riding must, "so reduce the incentive to produce the product or service that [the plaintiffs] existence or quality would be substantially threatened." 211 The producer of news may be engaged in more than one activity. The relevant question is whether it would be likely to abandon news gathering and reporting, not whether it would cease to exist at all. Finally, because a hot news policy requires a public investment it makes sense not to protect news based on events created by those who then purport to report the outcome as "news." In addition, a distinction should be made, if possible, between news that is important from the perspective of society and that which is principally entertainment. These elements are not easy to define but it is worthwhile to consider some possible approaches to defining the more difficult ones.

protection hinges on creation and originality rather than discovery.").

207 See generally Frontline, News War Part III: What's Happening to the News (PBS television broadcast Feb. 27, 2007), available at http://www.pbs.org/wgbh/pages/frontline/newswar/part3 (chronicling the downward spiral of the news industry, including the rise of internet-based news and its toll on readership of traditional media).

208 See generally Marcello, supra note 201.

209 Nat'l Basketball Ass'n v. Motorola, Inc., 105 F.3d 841, 845 (2d Cir. 1997).

$210 \mathrm{Id}$.

211 Id. 


\section{A. Time Sensitive}

The value of news is its "freshness"; 212 thus a plaintiff should not be able to prevail on a hot news claim for information that it reported years ago, or in some cases, even hours ago. The time sensitivity of hot news will vary. Assuming the other requirements were met, concert listings might retain their "hot" status for as long as they are valid because different people will check them every day. 213 Yet coverage of a hurricane moving ashore or a shooting spree may be hot for mere hours, or even less. The point is that hot news has a shelf life that depends partly on its content. Ideally, a hot news plaintiff will have to show that the defendant took the news before it cooled off.

This idea must be weighed against other factors. For example, suppose the news involves critical information that must be disseminated as a matter of public safety. In these instances a powerful argument can be made that public safety is given higher priority than the protection of hot news. The problem, though, is obvious. If all news sources were permitted to free ride on this critical information, it is possible the information may not be aggressively pursued in the first place.

Another factor to balance is the cost of administering the hot news policy itself. Ideally, each piece of news would have a "shelf life" beyond which it would be available to all. If the burden of proof on this is placed on plaintiffs, however, it greatly increases the cost and risk of enforcing hot news rights. One alternative is to shift the burden and provide defendants an opportunity to present a "no longer fresh" defense. By shifting the burden to defendants, the incidence of piracy should decline. This does not, however, address the definitional issue. Moreover, allowing the exclusive use of news by the plaintiff for longer than the minimum necessary means costs are imposed on the public in the form of monopoly prices for access or no access at all. A uniform period of exclusivity eliminates many of these costs and increases predictability. It would mean over and under protecting a great deal of news. Still, a uniform period has substantial appeal since it would set a definite property right about which parties could negotiate. Consequently, a fixed period of a few hours, with an exclusion for public emergencies, appears to be the most sensible balance.

212 Int'l News Serv, v. Associated Press, 248 U.S. 215, 238 (1918).

213 Pollstar v. Gigmania, 170 F. Supp. 2d 974, 980 (E.D. Cal. 2000) (rejecting defendant's motion to dismiss a claim of hot news misappropriation for taking concert listings from plaintiff's website). In all likelihood these listings would not be regarded as hot news under the functional approach here. The acquisition of concert and movie listings hardly require the news gatherer to incur significant costs. Indeed, this information is made available by those with commercial interests in hopes it will be reported. 


\section{B. Effort and Expense}

The plaintiff must expend time and money in generating information before having a hot news right. If not, there is no need to facilitate the internalization that a hot news policy provides. True news organizations should meet this element easily because they invest heavily in reporting staff and the infrastructure to support them.214 This requirement imposes an important limitation. As already noted, some news is simply available without investment. For example, many newspapers publish paid obituaries, which are written by the deceased's family or the funeral home handling the arrangements. In this situation, the newspaper has not allocated resources to collect and confirm the obituaries, and the paper actually makes money off the information. 215 Once these tributes to the deceased are published, the newspaper should not have hot news rights in the obituaries. In this connection, a great deal of "news" is also the result of aggressive publicity seeking. While it is not paid for by those seeking publicity, it is more or less thrust on news carriers. This too should be regarded as casually acquired and not protected.

\section{Direct Competition}

Some commentators have questioned whether direct competition is necessary in a hot news claim, asserting that the requirement is outdated because non-competitors can undermine the plaintiff's hot news as easily as a competitor. ${ }^{216}$ Nevertheless, direct competition should be regarded as a requirement in part because there are different interests involved than those in copyright.217 The author of a

214 Nick Gamse, Comment, Legal Remedies for Saving Public Interest Journalism in America, 105 NW. U. L. REV. 329, 334 (2011). Gamse explains:

$[\mathrm{N}]$ ewspaper journalists generate the vast majority of the original reporting in America with one estimate pegging their content contribution at as much as $85 \%$. As the foundation of the news industry, newspapers employ three times as many journalists as any other single news medium. Other news media, such as blogs, radio, and television, typically "piggyback" on newspapers' original coverage, repackaging the content for distribution through their respective channels. Industry analysts report that these other media channels simply lack the resources and expertise to fill the void that would be left by the widespread demise of the newspaper industry.

Id.

215 Nigel Starck, Obituaries for Sale: Wellsprings of Cash and Unreliable Testimony, 2 JOURNALISM PRAC. 244 (2008) (describing the rise in paid obituaries in American and Canadian newspapers).

216 Jensen, supra note 206, at 572 ("The law should not require [direct competition] because the internet has fundamentally changed the nature of competition.").

217 This is not to say that copyright does not also consider competitive effects. A defendant 
copyrighted work does lose something of value in the form of a missed sale when a work is downloaded. In the case of hot news, the loss is generally in the form of lost revenue because a competitor in the "news industry" is selling information that it did not gather. In short, a hot news policy should expressly recognize the unfair competitive element of hot news piracy. The INS court emphasized this point when it explained that AP's right in the news was enforceable against INS but not the public at large.218 Additionally, the U.S. Supreme Court has hinted more recently that this requirement is needed. In an admittedly "cryptic" sentence, 219 Justice O'Connor stated in Feist that while copyright cannot cover factual information, such "fruits" may be protected "in certain circumstances... under a theory of unfair competition." 220 The "certain circumstances" could be the type of unfair tactics that drove AP to sue All-Headline News. Unfair competition is the driving force of that claim.

Without this requirement, there is a danger that hot news would be too broad. Under the 1918 facts of INS, AP could not have been successful against a defendant who purchased a newspaper, clipped out the AP stories, and pinned the articles on a bulletin board for anyone to read. ${ }^{221}$ Likewise in 2012, AP should not win a hot news claim against a blogger who uses the facts from its stories to pontificate on the presidential election or the summer crop of blockbuster movies. The reality is that in neither of these cases does the user take income that would otherwise accrue to the original publisher.

\section{What Kind of News Is Protected?}

Perhaps the most difficult and controversial issue is what types of news is protected. As noted earlier, an absolutist approach avoids the value judgments involved in determining whether information is worthy of hot news protection. Another proposal requires judges to inquire "whether protecting the plaintiff s information will provide a tangible, useful benefit to society." 222 This nebulous condition might be easy to satisfy when the information involves the governmental or political reporting traditionally associated with the media's role in a

\footnotetext{
who competes with an author is less likely to employ successfully a fair use defense.

218 Int'l News Serv. v. Associated Press, 248 U.S. 215, 239 (1918) ("[A]ny purchaser of a newspaper has the right to communicate the intelligence which it contains to anybody and for any purpose.").

219 S. Leigh Fulwood, Feist v. Rural: Did the Supreme Court Give License to Reap Where One Has Not Sown?, 9 Comm. LAW. 15, 16 (1991).

220 Feist Publ'ns v. Rural Tel. Serv. Co., 499 U.S. 340, 354 (1991).

221 Int'l News Serv., 248 U.S. at 239.

222 Westley, supra note 84 , at 718 .
} 
democracy. But a judge may question the societal benefit of much hot news, such as the details on fashion designers' upcoming spring collections or the latest gossip on celebrity hookups.

The problem is not whether misappropriation occurs in the context of seemingly less important news. No doubt it does. In fact, there is a compelling argument that requiring judges to determine whether information is beneficial to society has no place in the realm of hot news. This point of view is consistent with focusing the inquiry on the relationship between the parties and the effort expended in uncovering the information.

On the other hand, a hot news policy is not costless. An absolutist policy maximizes the breadth of the subject matter under protection and raises the costs of the system. In a sense it would replicate the plight of copyright courts that constantly deal with trivial matters in which the public interest is very hard to discern.223 $\mathrm{A}$ hot news policy could avoid this problem by having a standard with respect to news that would be comparable in copyright to a higher level of originality.

If this goal were pursued, there are two guiding standards. First, news based on staged events would not be protected. This guideline is somewhat easier to grasp than a second one: news with a primarily entertainment purpose would not be protected. In both cases, the key is that there is an unlimited supply of celebrity divorces and breakups and rumors about them, fashion statements, gossip, and all manner of other information that may be interesting but hardly important. It is very difficult to equate these relatively fungible events with news that requires careful research and expert reporting. This may seem like a dangerous line to draw but, in fact, in many cases those who are subjects of this type of news want their news to be reported. Since news gatherers and reporters can rely on sources to make this news available at minimal if any cost, it fails the test of whether the information involved an investment.

\section{E. Remedies}

In addition to the factors already explored, a well-crafted federal hot news law should provide a range of remedies. It should include injunctive relief as well as damages, along with an award of attorney's fees in exceptional circumstances, such as bad-faith claims filed to harass a competitor. However, some have suggested that hot news remedies must be confined to damages because of the special concerns

223 See, e.g., Emanation Inc. v. Zumba Recording, Inc., 72 F. App'x 187 (5th Cir. 2003) (per curiam); Sherry Mfg. Co. v. Towel King of Fla., Inc., 753 F.2d 1565 (11th Cir. 1985); see also Harrison, supra note 108 , at $856-60$. 
raised in enjoining speech 224 and because of the factual information at issue. ${ }^{225}$ Another option would be to create compulsory licensing so that hot news violators could continue to use a competitor's information, but they would have to pay for doing so. Nearly 100 years ago, Justice Brandeis articulated this distrust against injunctions when he explained that "the right to news values should be protected to the extent of permitting recovery of damages for any unauthorized use but that protection by injunction should be denied." $226 \mathrm{He}$ suggested that hot news could follow copyright law by providing damages according to a statutory scheme.227

While the reluctance to impose injunctions in hot news situations is understandable, a lack of injunctive relief would gut the doctrine.228 Many blogs are one-person operations that often would be judgment proof, making an award of actual or statutory damages meaningless. 229 Because hot news claims typically will arise between big news operations that churn out the content and little operations that take it, injunctions play a crucial role in stemming free riders. Moreover, an injunction for hot news claims almost always will be temporary. ${ }^{230}$ This means that Justice Brandeis's instinctive concerns about injunctions are not as relevant in this context. The hot news will become available eventually, so the injunction is not freezing speech in the manner that the U.S. Supreme Court finds most problematic. ${ }^{231}$ Additionally defendants in hot news cases always have the option to cultivate the information on their own. Thus, if defendants do not want to wait out injunctions, they can get around them with independent reporting. ${ }^{232}$

\section{CONCLUSION}

Hot news is a public good. Exclusivity is necessary to encourage its gathering and reporting at desirable levels. State by state law is inadequate because it confuses geographic and political borders with

224 See Gregory, supra note 1, at 612 .

225 Balganesh, supra note 55, at 482-83 (questioning the advisability of awarding injunctive relief when the property at issue is factual news, which should remain "unowned, in the commons, and freely accessible by all").

226 Int'l News Serv., 248 U.S. at 266 (Brandeis, J., dissenting).

227 See 17 U.S.C. $\$ 504$ (2012) (allowing a successful copyright plaintiff to recover actual damages or statutory damages, set between $\$ 750$ and $\$ 30,000$ as “the court considers just").

228 Gregory, supra note 1, at 612 .

229 Id. at 613.

230 The district court in Barclays I crafted an injunction that would have prevented The Fly from publishing the contested information for the first thirty minutes after the opening of the market. Barclays $I I, 650$ F.3d 876, 889 (describing the district court's injunction).

231 See Neb. Press Ass'n v. Stuart, 427 U.S. 539, 559 (1976) (explaining that an injunction "freezes" speech).

232 Westley, supra note 84 , at 728. 
communication markets or borders. Thus, federal legislation is appropriate. This legislation should be drafted in a manner than avoids intertwining news reporting with copyright. To this end, the proposal here would allow exclusive use for a limited time when the news is gathered and reported at a cost and then taken by competitors. Although the specifics are not free from doubt, it suggests a single period of exclusivity for all hot news in order to avoid the uncertainty and risk of a sliding scale and the added costs of administering a hot news regime. Also, although possibly controversial, it proposes a policy that requires judges to distinguish news based on whether it has social importance as opposed to pure entertainment value. The sense is that, like many ordinary products, entertainment news is essentially fungible and the likelihood of a shortage due to an inability to internalize is remote. 


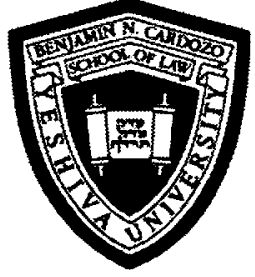

